\title{
Trends in Precursor Design for Conventional and Aerosol-assisted CVD of High- $T_{c}$ Superconductors
}

\author{
Liliane G. Hubert-Pfalzgraf* and Hervé Guillon \\ Laboratoire de Chimie Moléculaire, URA-CNRS, Parc Valrose, 06108 Nice Cedex, France.
}

Conventional MOCVD techniques require molecules displaying volatility and constant vapor pressure. Metal oxide precursors, i.e., $\beta$-diketonates, or classical or functionalized metal alkoxides are mostly solids. The various approaches used to tailor volatility are discussed with barium derivatives as an example. The relationships between sublimation temperature and molecular weight suggest that volatility can be optimized on the basis of molecular weight.

Aerosol-assisted CVD (AACVD) can use a larger range of precursors since volatility is no longer crucial. The solvent is an undesired ballast in a CVD process. High solubility of the precursors in the selected solvent is thus desirable. 'Stability' here includes the absence of precipitation which would change the stoichiometry of the feed solution for multicomponent oxides. Precipitation is often promoted by hydrolysis; stability toward moisture is thus desirable. The use of mixtures of precursors based on different ligands ( $\beta$-diketonates, $\beta$ ketoesterates, alkoxides) can lead to ligand exchange reactions giving homometallic species, sometimes of low solubility, or mixed-metal species by self-assembly, thus improving solubility and stability toward moisture. These aspects are illustrated in compositions related to high- $T_{\mathrm{c}}$ superconductors. Novel copper, yttrium, cerum(IV), barium-copper, yttriumcopper and praseodynium-copper species are reported. (C) 1998 John Wiley \& Sons, Ltd.

Appl. Organometal. Chem. 12, 221-236 (1998)

Keywords: MOCVD; barium; liquid delivery; mixed-metal species; aerosol-assisted CVD

Received 10 February 1997; accepted 16 May 1997

*Correspondence to: Liliane G. Hubert-Pfalzgraf, Laboratoire de Chimie Moléculaire, URA-CNRS, Parc Valrose, 06108 Nice Cedex, France.

Contract/grant sponsor: EEC; Contract/grant number: BRE2-CT940742 .

\section{INTRODUCTION}

The current trend in advanced materials technology is to produce devices which are compact for (integrated circuit technology) and reliable, with fast responses. The processes for film-making or coating processes are therefore increasingly in demand. ${ }^{1}$ Common thin-film processing techniques are physical methods or chemical routes, namely metal-organic deposition (MOD), the sol-gel process and chemical vapor deposition (CVD). ${ }^{2}$ Although the sol-gel process offers unique opportunities for hybrid (organic-inorganic) materials, ${ }^{3}$ metal-organic chemical vapor deposition (MOCVD) is a more appealing technique for electronic applications. It has been established as a very useful fabrication process for the deposition of high-quality epitaxial films, for conformal step coverage and for selective growth, which are unique attributes of CVD. MOCVD is also a cheap and versatile method, working without expensive vacuum equipment by comparison with physical methods. However, volatile precursors with a sufficient thermal stability during the evaporation process are required to function as a carrier for the material to be deposited. Being non-reactive with each other in the vapor phase is an additional need for multimetallic materials.

Molecular chemistry offers a large flexibility for the choice of ligands in order to fulfill the requirements of MOCVD precursors. However, meeting the criteria is still challenging for some elements, e.g. for barium ${ }^{4,5}$ or cerium $^{6-8}$ oxide precursors, and significant deficiencies still exist with respect to vapor pressure and vapor-pressure stability. Indeed, a low charge on a metal ion combined with a large ionic radius (e.g. $\mathrm{Ba}^{2+}$ ) causes considerable problems when attempting to achieve volatility. The demands for large ligands for limitation of the nuclearity - and low molecular weight are conflicting and not easily achieved. For precursors of low volatility, viable alternatives to the classical transport methods have recently been 
proposed. $^{9}$ They include spray pyrolysis, direct liquid injection, aerosol-assisted CVD (AACVD), supercritical fluid transport (in carbon dioxide), ${ }^{10}$ and flash evaporation of the solid. For these emerging delivery technologies, liquid precursors or solutions of precursors in organic solvents are used. A wider variety of metal-containing compounds in terms of thermal stability and volatility can be considered.

After a brief survey of the state-of-the-art for conventional MOCVD, we wish to illustrate some of the strategies which can be used for the tailoring of suitable precursors for AACVD of superconductors and/or of their buffer layers. Indeed, for many important applications, it would be useful to deposit YBCO layers directly on a metallic substrate; buffer layers may thus be required. This report is not intended to be an extensive review and the structural data on barium derivatives will only be briefly outlined since the structural chemistry of barium $\beta$-diketonates has been reviewed recently. ${ }^{11}$

\section{STATE-OF-THE-ART FOR THERMAL MOCVD}

\section{General considerations}

Novel technologies are likely to rely on integrated multicomponent oxides (titanates, niobates, tantalates) and high- $T_{\mathrm{c}}$ superconductors. The formulations of these perovskite-type materials are based on large elements, alkaline-earth metals, lead or bismuth, and early transition metals or lanthanides.

The precursors for CVD of such materials are predominantly metal alkoxides $\mathrm{M}(\mathrm{OR})_{n}$ and $\beta$ diketonates $\mathrm{M}\left(\mathrm{RCOCHCOR}^{\prime}\right)_{n}$ and, to a lesser extent, alkyl or cyclopentadienyl derivatives. ${ }^{2}$ Volatile hydroxylamides $\mathrm{M}\left(\mathrm{ONR}_{2}\right)_{4}(\mathrm{R}=\mathrm{Me}, \mathrm{Et})$ have also been reported for Group 4. ${ }^{12}$ Most of these compounds are solids and their stability is usually estimated by repeated sublimations. The traditional delivery techniques used for solids and/ or liquids with low vapor pressures are direct sublimation or inert or reactive gas-bubbler methods. These require well-controlled, high-temperature delivery lines they can be in order to avoid condensation of the precursors. The complexity of the delivery systems increases with the number of lines required for a multicomponent material. ${ }^{13}$ The mass transport of a solid is a function of the surface area of the powder and therefore the effective transport rate drops as the solid is consumed.
MOCVD precursors which are liquid at the temperature of use would thus offer greater filmgrowth efficiency and vapor pressure stability. ${ }^{14,15}$ Moreover, some precursors are unstable at high temperature over long periods of time. The quest for more stable and more volatile barium oxide precursors needed for ferroelectrics or high- $T_{\mathrm{c}}$ superconductors is an example of the challenges in precursor chemistry in order to ensure reproducibility of the deposits, scale-up and thus industrial applications. This survey is focused essentially on barium derivatives. Suitable CVD precursors are available for most lanthanides except cerium. ${ }^{16}$

The volatility of a compound is a complex function of intermolecular forces (van der Waals interactions, $\pi$-stacking or hydrogen bonds) which are affected by molecular weight and geometry and, for solids, lattice structure. Control of the oligomerization in the solid state and in the vapor by the steric bulk of the ligands, manipulation of Lewis acid-base reactions and thus formation of adducts, and use of fluorinated ligands represent the main directions for tailoring volatility.

Scheme 1 collects some of the O- and N-donor anionic and neutral ligands which have been used for molecular oxide precursors.

\section{$\beta$-Diketonates and their adducts}

$\beta$-Diketonates $\mathrm{M}\left(\mathrm{RCOCHCOR}_{n}^{\prime}\right.$ represent the predominant type of precursors used so far for access to high- $T_{\mathrm{c}}$ superconductors by thermal MOCVD. It is well known that steric hindrance on the $\alpha$-carbon atom favors volatility. 2,2,6,6,-Tetramethylheptane-3,5-dionates $\mathrm{M}(\text { thd })_{n}$, based on $\beta$-diketones where $\mathrm{R}=\mathrm{R}^{1}=t \mathrm{Bu}$ and which are commercially available, are thus usually the best choice for non-fluorinated derivatives. ${ }^{2}$ Whereas the vapor pressures are satisfactory for yttrium (as well as for trivalent lanthanides) and copper tetramethylheptanedionates, the situation is less favorable for barium. The large size of the alkalineearth metals, especially for barium, results in coordinative unsaturation, and barium tetramethylheptanedionate cannot be described by a simple formula such as $\mathrm{Ba}$ (thd) $)_{2}{ }^{3}$ By contrast with the monomeric nature of the yttrium and copper derivatives, barium tetramethylheptanedionate actually corresponds to a tetramer $\left[\mathrm{Ba}_{4}(\text { thd })_{8}\right],{ }^{17,18}$ to pentanuclear clusters $\left[\mathrm{Ba}_{5}\left(\mu_{5}-\mathrm{X}\right)(\text { thd })_{9}\left(\mathrm{H}_{2} \mathrm{O}\right)_{n}\right]$ $\left(\mathrm{X}=\mathrm{OH}, \quad n=3 ;{ }^{19} \quad \mathrm{X}=\mathrm{C} 1, \quad n=7\right)^{20} \quad$ or $\left[\mathrm{Ba}_{5}(\text { thd })_{9}(\right.$ piv $\left.)\right]\left(\right.$ piv $=$ pivalate $\left.=t \mathrm{BuCO}_{2}\right),{ }^{21}$ or to the hexamer $\left[\mathrm{Ba}_{6}(\text { thd })_{12}\left(\mathrm{H}_{2} \mathrm{O}\right) 13\right],{ }^{22}$ depending on the method of preparation. Of particular importance 
<smiles>[R]C(=O)C=C([R])[O-]</smiles>

\section{$\beta$-diketonates}

thd $=$ tetramethylheptanedionate $\left(\mathrm{R}=\mathrm{R}^{\prime}=\mathrm{Bu}^{\mathrm{t}}\right)$ $\mathrm{tfa}=$ trifluoroacetylacetonate $\left(\mathrm{R}=\mathrm{CF}_{3}, \mathrm{R}^{\prime}=\mathrm{Me}\right)$ $\mathrm{hfa}=$ hexafluoroacetylacetonate $\left(\mathrm{R}=\mathrm{R}^{\prime}=\mathrm{CF}_{3}\right)$<smiles>CNCC(O)CN(C)C</smiles><smiles>CC(O)CC(C)N(C)C</smiles>

OR' ${ }_{N}$<smiles>COCCOC</smiles><smiles>CCCOCCOC(C)C</smiles>

diglyme $\quad \mathrm{n}=1$ triglyme $\quad n=2$ tetraglyme $n=3$<smiles>[R]OC(=O)C=C([R])[O-]</smiles>

$\beta$-ketoesterates $\mathrm{R}=\mathrm{Bu}^{\mathrm{t}}$
$\mathrm{R}^{\prime}=\mathrm{Me}$<smiles>CN(C)CCO</smiles>

ORn

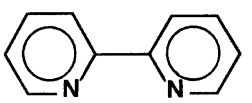

2,2'-bipyridyl (bipy)<smiles>[R]C(=[W])C=C([R])[R]</smiles>

$\beta$-ketoiminates

$\mathrm{R}=\mathrm{Bu}^{\mathrm{t}}$ $\mathrm{R}^{\prime}=\mathrm{C}_{2} \mathrm{H}_{4} \mathrm{OMe},\left(\mathrm{C}_{2} \mathrm{H}_{4} \mathrm{O}\right)_{2} \mathrm{Me}$
$\mathrm{R}^{\prime \prime}=\mathrm{Me}$ or $\mathrm{Bu}^{t}$<smiles>CNCc1cc(CN(C)C)cc(CN(C)C)c1O</smiles>

Otamp

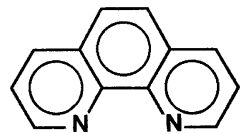

1,10-phenanthroline (o-phen)

Scheme 1 Some O- and N-donor anionic and neutral ligands used for molecular oxide precursors.

are the natures of the solvent, aqueous or nonaqueous, and of the barium source, barium hydroxide, chloride or nitrate. The method of purification can also be crucial. Gleizes et al. obtained the dimer $\left[\left\{\mathrm{Ba}_{2}(\mathrm{thd})_{4}(\mathrm{MeOH})_{6}\right\}(\mathrm{MeOH})_{2}\right]$. The compound was prepared in a queous medium using $\mathrm{Ba}(\mathrm{OH})_{2}$ and recrystallized from methanol, ${ }^{23}$ a synthetic procedure which was also reported to lead to $\left[\mathrm{Ba}_{5}\left(\mu_{5}-\mathrm{OH}\right)(\text { thd })_{9}\left(\mathrm{H}_{2} \mathrm{O}\right)_{3}\right]$ by recrystallization in pentane. ${ }^{19}$ The different types of aggregation allow the metal to increase its coordination number to six, seven or even eight. 'Ba(thd $)_{2}$ ' can thus display quite different structures and thus properties in term of volatility and stability. The variations of physical properties are revealed, for instance, by the large range of melting points reported. The presence of residual solvent (often an alcohol), acting as a Lewis base in some commercial samples, is another aspect of the poor control of the properties of the barium oxide precursor. Sample prehistory is an important feature for volatility and stability characteristics. A decrease in the volatility with aging is also common for these precursors. Neutral or anionic hexanuclear peroxo derivatives based on a
$\left[\mathrm{Ba}_{6}\left(\mathrm{O}_{2}\right)_{2}(\text { thd })_{10}\right]$ core have been reported and structurally characterized. ${ }^{24,25}$ Their formation might also account for the unstable vapor pressure characteristics. The factors favoring their formation remain poorly known.

Sterically hindered methoxy- $(\beta)$-diketones $\mathrm{RR}^{\prime} \mathrm{C}(\mathrm{OMe}) \mathrm{COCH}_{2} \mathrm{COR}^{\prime \prime}$ have been developed recently for barium. The introduction of bulky end-substituents into the ligand does not reduce the degree of oligomerization in the vapor phase, but increases the thermal stability of the compounds. ${ }^{26}$

Numerous attempts to synthesize volatile barium compounds have been described. Complexation has been widely used as a means to obtain a second, more stable, generation of precursors. The formation of complexes of barium tetramethylheptanedionate proceeds readily with nitrogen or oxygen donors. The nuclearity of the precursors is decreased. Dimers such as $\left[\mathrm{Ba}(\mathrm{thd})_{2} \mathrm{~L}_{2}\right]_{2} \quad(\mathrm{~L}=$ $\mathrm{NH}_{3}, \mathrm{Et}_{2} \mathrm{O}, 1 / 2$ diglyme, ${ }^{27}$ (1/2 bipy) and monomers such as $\left[\mathrm{Ba}(\text { thd })_{2}(\mathrm{TMEDA})_{2}\right] \quad(\mathrm{TMEDA}=$ $\mathrm{N}, \mathrm{N}, \mathrm{N}^{\prime}, \mathrm{N}^{\prime}$-tetramethylethylenediamine $)^{28}$ or $\left[\mathrm{Ba}(\mathrm{thd})_{2}\right.$ (triglyme)] are representative examples of the complexes obtained. ${ }^{11}$ The melting points 
decrease relative to $\left[\mathrm{Ba}_{4}(\text { thd })_{8}\right]$; this is a common and interesting feature. ${ }^{23}$ However, a critical and less favorable aspect is their thermal behavior.

Indeed, the thermal behavior of these Lewis acid-base adducts is plagued by ligand dissociation reactions occurring during the transport into the vapor phase. The extent of dissociation during or before sublimation depends on the stability of the complexes. ${ }^{29,30}$ The complexes based on monodentate donors dissociate completely, whereas those based on tridentate ligands are partially dissociated. Dissociation of $\mathrm{ca} 65 \%$ has for instance been reported for $\left[\mathrm{Ba}(\text { thd })_{2}(\operatorname{deta})\right] \quad(\operatorname{deta}=$ diethylenetriamine $\left.=\mathrm{NH}_{2} \mathrm{C}_{2} \mathrm{H}_{4} \mathrm{NHC}_{2} \mathrm{H}_{4} \mathrm{NH}_{2}\right)^{29,30}$ Addition of the Lewis base in the carrier gas in therefore required for improving the transport into the vapor. The presence of Lewis bases improves the storage stability of $\mathrm{Ba}$ (thd) $)_{2}$ (the coordination number of the metal is higher), but the formation of hydrates remains possible as shown by the formation of $\left[\mathrm{Ba}_{2}(\text { thd })_{4}(\text { diglyme })_{2}\left(\mu-\mathrm{H}_{2} \mathrm{O}\right)\right]$ in which two

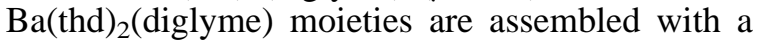
water molecule, and which has been structurally characterized. $^{31}$

Barium fluorinated $\beta$-diketonates are stronger Lewis acids, so their complexes are more stable. $\left[\mathrm{Ba}(\mathrm{tfa})_{2}\right.$ (tetraglyme)] (tfa = tetrafluoroacetate) for instance, is transported into the vapor as the initial adduct. $^{32,33}$ An appropriate choice of the Lewis base can allow a notable decrease in the melting point of the complex and use as a liquid barium precursor. ${ }^{34}$ Indeed, whereas the melting point of $\left[\mathrm{Ba}(\mathrm{hfa})_{2}\right.$ (tetraglyme) $]$ is $152^{\circ} \mathrm{C},{ }^{32,33}$ that of the unsymmetrical polyether adduct $\left[\mathrm{Ba}(\mathrm{hfa})_{2}\{\mathrm{MeO}-\right.$ $\left.\left.\left(\mathrm{C}_{2} \mathrm{H}_{4} \mathrm{O}\right)_{6} n \mathrm{Bu}\right\}\right]$ is only $\mathrm{ca} 52^{\circ} \mathrm{C}$, making possible its use for long time periods without the interruption necessary for pulverizing the sintered samples to restore their volatility. ${ }^{34}$ Secondary Ba $\cdots$ F bonds are often observed in the solid state for fluorinated -diketonates. ${ }^{35,36}$ However, if such bonds are favorable for saturation of the coordination sphere, they can also promote contamination of the deposits by barium fluoride. Defluorination by heating the films in an $\mathrm{H}_{2} \mathrm{O}-\mathrm{O}_{2}$ atmosphere is then necessary. Such precursors can however find application for fluoride glasses or photo-ionic materials. ${ }^{37,38}$

The sizes of calcium or strontium ions, smaller than that of barium, are more favorable for volatility since they have lower coordination numbers. On the other hand, barium can best accommodate Lewis bases in terms of size. However, the acidity of the metal center is also a determining factor in the stability of acid-base adducts. Acidity varies in the order $\mathrm{Ca}^{2+}>\mathrm{Sr}^{2+}>\mathrm{Ba}^{2+}$. The effects of size and acidity on the thermal stability lie in opposite directions; the stability of the adduct will thus often be determined by the ligands. ${ }^{39}$ Whereas no definite evidence has been found for a $\mathrm{Ba}(\text { thd })_{2}(\text { thd })_{x}$ adduct although such a species has been suggested to favor transport into the vapor, the strontium derivative $\left[\mathrm{Sr}_{3}(\mathrm{thd})_{6}(\mathrm{thdH})\right]$ has been suggested to favor the transport into the vapor, the strontium derivative $\left[\mathrm{Sr}_{3}(\mathrm{thd})_{6}(\mathrm{thdH})\right]$ has been structurally characterized. 40

\section{Alkoxides and aryl oxides}

Saturation of the coordination sphere can be achieved by using encumbered anionic ligands, alkoxides or aryl oxides substituted in the 2- and 6positions, for instance. Such ligands offer the advantage over $\beta$-diketonates of being relatively easily tailored with appendage, 'spacer' and additional donor sites the last affording the possibility of forming complexes stabilized by intramolecular coordination. ${ }^{16,41}$ Several attempts with ether or amine donor sites have been reported. Metal alkoxides or aryl oxides are, however, moisturesensitive and thus require more care in their handling than $\beta$-diketonates.

Barium alkoxides, including derivatives supported by functional or fluorinated alkoxides or bulky aryl oxides, are generally either non-volatile, or volatile in conditions too drastic for CVD applications, as they usually correspond to oligomers. Typical compounds are $\left[\mathrm{Ba}_{5}(\mu-\mathrm{OH})\right.$ $\left.(\mathrm{OAr})_{9}(\mathrm{THF})_{5}\right]\left(\mathrm{Ar}=\mathrm{C}_{6} \mathrm{H}_{3}(t \mathrm{Bu})_{2}-2,6 \mathrm{THF}=\right.$ tetrahydrofuran $),{ }^{42}\left[\mathrm{Ba}_{5}\left(\mu_{5}-\mathrm{OH}\right)(\mathrm{ORf})_{9}(\mathrm{THF})_{4}\left(\mathrm{H}_{2} \mathrm{O}\right)\right]^{43}$ $\left[\mathrm{Rf}=\mathrm{CH}\left(\mathrm{CF}_{3}\right)_{2}\right] \quad$ or $\quad\left[\mathrm{H}_{4} \mathrm{Ba}_{6}\left(\mu_{6}-\mathrm{O}\right)-\right.$ $\left.\left(\mathrm{OC}_{2} \mathrm{H}_{4} \mathrm{OMe}\right)_{14}\right]{ }^{44}\left(\mathrm{H}_{4}\right.$ stands for hydroxyl hydrogen which could not be located.) The nuclearity of bulky alkoxides or aryl oxides has been in part controlled by the presence of THF, affording monomers or dimers. No data on their volatility and/or thermal behavior have been reported. ${ }^{45}$ Volatile solvent-free alkaline-earth metal alkoxides based on trifunctional alcohols such as $\mathrm{OHC} t \mathrm{Bu}$ $\left(\mathrm{CH}_{2} \mathrm{OR}\right)_{2}(\mathrm{R}=\mathrm{Et}$, $i \mathrm{Pr})$ have been reported recently. ${ }^{46,47}$ They are dimeric in the solid state as well as in the gas phase, and display well-defined sublimation temperatures $\left(185^{\circ} \mathrm{C} / 7.5 \times 10^{-3}\right.$ Torr for $\mathrm{R}=i \mathrm{Pr}$ ).

The partial substitution of alkoxide ligands by $\beta$ diketonates, the latter acting essentially as chelating ligands, could be a means to reduce oligomerization and thus to increase the volatility. Lower hydrolytic susceptibility could be an additional benefit. However, barium $\beta$-diketonatoalkoxides also dis- 
play a high nuclearity, generally four or five, even for functionnal alkoxide ligands. Compounds such as $\left[\mathrm{H}_{2} \mathrm{Ba}_{4}(\text { thd })_{6}\left(\mathrm{OC}_{2} \mathrm{H}_{4} \mathrm{O} i \mathrm{Pr}\right)_{4}\right]^{48}\left(\mathrm{H}_{2}=\right.$ unlocated hydroxyl hydrogen) and $\left[\mathrm{Ba}_{5}\left(\mu_{5}-\mathrm{OH}\right)(\text { thd })_{5}(\mathrm{OCH}-\right.$ $\left.\left.\mathrm{MeCH}_{2} \mathrm{NMe}_{2}\right)_{4}\right]^{49}$ illustrate that trend. Finally, if such compounds can display properties pertinent for sol-gel applications, the combination of alkoxide and $\beta$-diketonate ligands has generally not achieved better volatility and/or stability of barium derivatives. TGA data show that the alkoxide ligand is generally more thermally labile than the -diketonate.

Siloxide ligands $\mathrm{OSiR}_{3}$ are generally considered to decrease the hydrolytic susceptibility with respect to common metal alkoxides. ${ }^{2}$ Their steric effect can be tuned by the choice of R. However, even ligands as sterically demanding as triphenyl siloxide form oligo- and poly-nuclear compounds of low volatility for barium. ${ }^{50}$ Oligomerization can be limited if the synthesis is achieved in the presence of a polydentate ether, namely 15crown-5. The barium and strontium monomers $\left[\mathrm{M}\left(\mathrm{OSiPh}_{3}\right)_{2}(15\right.$-crown-5)(THF)]THF are obtained. ${ }^{51}$ However, none of these complexes sublimes intact, and undefined polymers ' $\mathrm{M}\left(\mathrm{OSiPh}_{3}\right)_{2}$ ' are obtained after ligand dissociation. Moreover, thermogravimetric analyses indicate that the solids are actually $\mathrm{MSi}_{2} \mathrm{O}_{5}$ silicates. Silyl ether elimination can be achieved in solution, however, in the presence of titanium isopropoxide, giving a mixed-metal oxo intermediate whose thermolysis leads to crystalline barium titanate. These observations indicate that the thermal behavior of a precursor can be modified by the other metallic species, the OR groups of titanium isopropoxide assisting the elimination of the $\mathrm{SiPh}_{3}$ groups.

\section{Miscellaneous}

Non-volatile barium and strontium fluorinated carboxylates have been reported as polyether adducts. ${ }^{52}$ Their thermal decomposition in the solid state gives metal fluorides. However, the reactivity is different in the presence of $\mathrm{Ti}(\mathrm{Oi} \mathrm{Pr})_{4}$ and $\mathrm{BaTiO}_{3}$ is then obtained.

Monomeric or dimeric barium $\beta$-ketoiminate complexes containing appended ether 'lariats' have been reported. $\mathrm{Ba}\left[\mathrm{RCOCHC}\left(\mathrm{NR}^{\prime}\right) \mathrm{R}^{\prime \prime}\right]_{2} \quad(\mathrm{R}=t \mathrm{Bu}$, $\mathrm{R}^{\prime}=\mathrm{C}_{2} \mathrm{H}_{4} \mathrm{OMe}\left(\mathrm{C}_{2} \mathrm{H}_{4} \mathrm{O}\right)_{2} \mathrm{Me}, \quad\left(\mathrm{C}_{2} \mathrm{H}_{4} \mathrm{O}\right)_{3} \mathrm{Et}$ and $\mathrm{R}^{\prime \prime}=\mathrm{Me}$ or $\left.t \mathrm{Bu}\right)$ species have been used as a volatile source of barium oxide to obtain $\mathrm{BaPbO}_{3}$ films. However, these complexes display, as well as the $\beta$-diketonates, a limited thermal stability, as shown by the residues (up to $39 \%$; theoretical value for $\mathrm{BaO}=20 \%$ ) in the atmospheric-pressure TGA experiments. ${ }^{53}$

Hydridotris(3,5-dimethylpyrazolyl)borates have been reported for calcium, strontium and barium. ${ }^{54,55}$ The tridentate character of the ligand (as shown by X-ray diffraction studies) protects the metals from external reagents, moisture and oxygen. The compounds are volatile (sublimation at $200^{\circ} \mathrm{C}, 10^{-3}$ Torr) but no other data concerning their thermal behavior are available. Whereas the barium derivative displays good solubility properties in common organic solvents, the calcium and strontium analogs are only sparingly soluble.

Calcium, strontium and barium metallocenes $\mathrm{MCp}_{2}{ }_{2}$ based on bulky cyclopentadienyl ligands such as $t \mathrm{BuC}_{5} \mathrm{H}_{4}$ or $\mathrm{C}_{5} \mathrm{Me}_{5}$ or encapsulating ones such as $\mathrm{C}_{5} \mathrm{H}(i \mathrm{Pr})_{4}$ have been isolated and the trends of their physical properties discussed. ${ }^{39}$ Derivatives with a pendant pyridine functionality on the ring have also been developed. ${ }^{56}$ The nitrogen donor site interacts with the metal and thus limits the nuclearity.

\section{Volatile mixed-metal precursors}

Single-source precursors in which different metals are associated within the same molecule are accessible by a variety of strategies. Such compounds can be a means to increase stability and/or volatility of the barium precursors. ${ }^{57,58} \mathrm{~A}$ number of $\mathrm{Ba}-\mathrm{Cu},{ }^{59,60}$ a few $\mathrm{Y}-\mathrm{Ba}^{61}$ and $\mathrm{Y}(\mathrm{Ln})-\mathrm{Cu}^{62,63}$ species $(\mathrm{Ln}=$ lanthanides) have been reported. Requirements for classical MOCVD imply the use of assembling ligands forming strong bridges between the metals. Fluorinated alkoxides only have so far been able to retain the association between the different metals related to high- $T_{\mathrm{c}}$ superconductor formulations in the vapor phase, and to stabilize volatile species. ${ }^{64}$ The effect of $\beta$ diketonate ligands on volatility and stability is well illustrated with $\mathrm{Y}-\mathrm{Ba}$ fluoroisopropoxide species. $\left[\mathrm{Ba}_{2} \mathrm{Y}(\mathrm{ORf})_{7}(\mathrm{THF})_{3}\right]$ is volatile $\left(200^{\circ} \mathrm{C} / 10^{-3}\right.$ Torr, decomposition ca $\left.\left.200{ }^{\circ} \mathrm{C}\right)\left[\mathrm{Y}_{2} \mathrm{Ba} \text { (thd }\right)_{4}(\mu \text {-ORf })_{4}\right]$ whereas sublimes at $150^{\circ} \mathrm{C} / 10^{-3}$ Torr but decomposes at only $170{ }^{\circ} \mathrm{C}$. Other volatile heterometallic species, namely $\left[\mathrm{BaCu}_{2}(\text { thd })_{2}(\mathrm{ORf})_{4}\right]$ and $\left[\mathrm{YCu}(\mathrm{thd})_{3}(\mathrm{ORf})_{2}\right]$, have been obtained in high yield. ${ }^{65}$ Their vapor pressures are higher than these observed for the homometallic tetramethylheptanedionates (Fig. 1) and the association between the metals is retained in the vapor, as shown by mass spectrometry. Secondary Ba $\cdots$ F bonds complement the barium coordination sphere, allowing the metal 


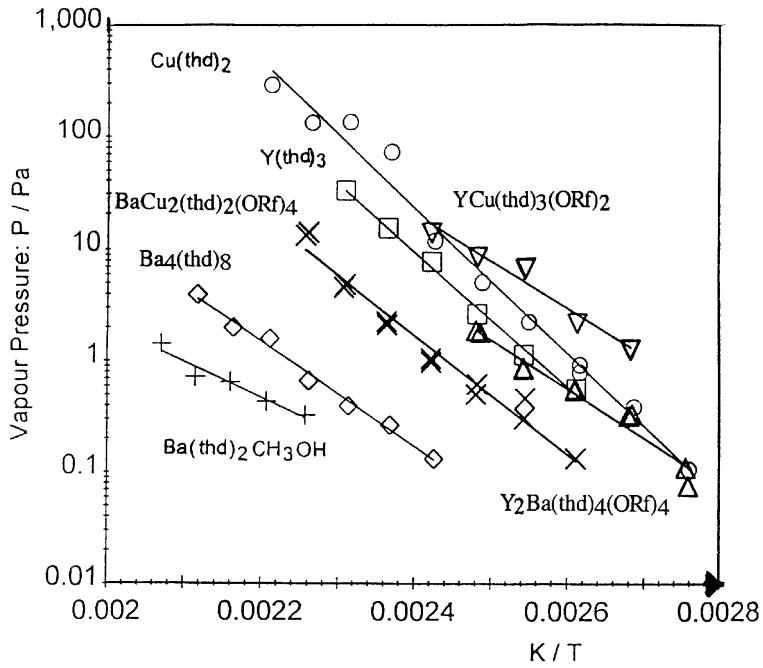

Figure 1 Comparison of the vapor pressure data of the mixed-metal fluoroisopropoxides $\quad \mathrm{Y}_{2} \mathrm{Ba}(\mathrm{thd})_{4}(\mathrm{ORf})_{4}$, $\mathrm{BaCu}_{2}(\text { thd })_{2}(\mathrm{ORf})_{4}, \mathrm{YCu}(\text { thd })_{3}(\mathrm{ORf})_{2}$ and of the homometallic tetramethylheptanedionates.

to reach a coordination number of 12 . The $\mathrm{Ba}^{2+}$ center is actually encapsulated between two $\mathrm{Y}(\mathrm{ORf})_{2}$ (thd $)_{2}{ }^{-}$units (Fig. 2). The coordination sphere of the central barium atom can be modified by various Lewis bases, decreasing the number of $\mathrm{Ba} \cdots \mathrm{F}$ interactions due to the fluoroisopropoxide groups which, in fact, act as semilabile ligands. Complexes such as $\left[\mathrm{Y}_{2} \mathrm{Ba}(\text { thd })_{4}(\mathrm{ORf})_{4}(\mathrm{TMEDA})_{2}\right]$ or $\left.\left[\mathrm{Y}_{2} \mathrm{Ba} \text { (thd }\right)_{4}(\mathrm{ORf})_{4}\left(\mathrm{Me}_{2} \mathrm{CO}\right)_{2}\right]$ have been isolated. ${ }^{65}$ The stability and volatility of the $\mathrm{Y}_{2} \mathrm{Ba}$ species can thus be tuned and the temperature window for effective use increased. One can also notice that Ba $\cdots \mathrm{F}$ interactions in the solid state and/ or in the vapor phase do not always imply the presence of fluoride residues in the material resulting from the decomposition. For instance, thermolysis of $\left[\mathrm{Ba}_{5}(\mu-\mathrm{OH})(\mathrm{ORf})_{9}(\mathrm{THF})_{4}\left(\mathrm{H}_{2} \mathrm{O}\right)\right]$ gives pure $\mathrm{BaF}_{2} .{ }^{43}$ On the other hand, the decomposition of $\left.\left[\mathrm{Y}_{2} \mathrm{Ba} \text { (thd }\right)_{4}(\mathrm{ORf})_{4}\right]$ in a hot-wall glass reactor leaves $\mathrm{Y}_{2} \mathrm{Ba}_{4} \mathrm{O}_{7}$ and $\mathrm{Y}_{2} \mathrm{O}_{3}$ with only traces of $\mathrm{BaF}_{2}$. Alkaline-earth metal fluorides have been obtained even in the absence of $\mathrm{M} \cdots \mathrm{F}$ interactions in the solid state, by using $\left[\mathrm{M}(\mathrm{hfa})_{2}\right.$ (tetraglyme)] for instance. ${ }^{56}$ These observations indicate that further studies are required for an understanding of the factors favoring the formation of fluoride residues. However, large differences in the stability are observed for the two mixed-metal precursors, $\left[\mathrm{BaCu}_{2}(\text { thd })_{2}(\mathrm{ORf})_{4}\right]$ and $\left[\mathrm{Y}_{2} \mathrm{Ba}(\text { thd })_{4}(\mathrm{ORf})_{4}\right]$, required for the nominal $\mathrm{YBa}_{2} \mathrm{Cu}_{3} \mathrm{O}_{7-x}$ composition and the parameters for obtaining films are thus difficult to adjust. Most of the $\mathrm{YBa}$ species are hygroscopic; $\left[\mathrm{Y}_{2} \mathrm{Ba}(\text { thd })_{4}(\mathrm{ORf})_{4}(\mathrm{THF})_{2}\left(\mathrm{H}_{2} \mathrm{O}\right)\right]$ has been obtained, for instance, and this affects the long-term stability and the reproducibility of the thermal behavior. Finally, if volatility can be

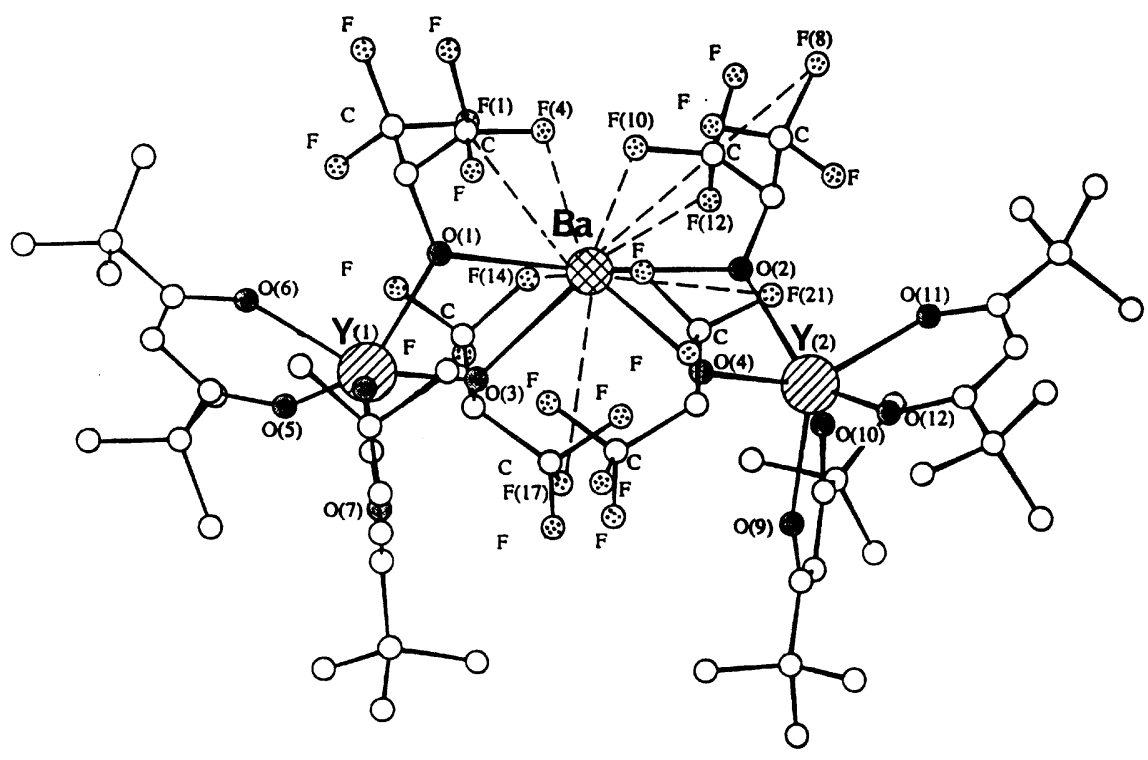

Figure 2 Structure of $\mathrm{Y}_{2} \mathrm{Ba}(\text { thd })_{4}(\mu \text {-ORf })_{4}$ showing the encapsulation and high coordination number of barium (broken lines indicate $\mathrm{Ba}-\mathrm{F}$ interactions). 


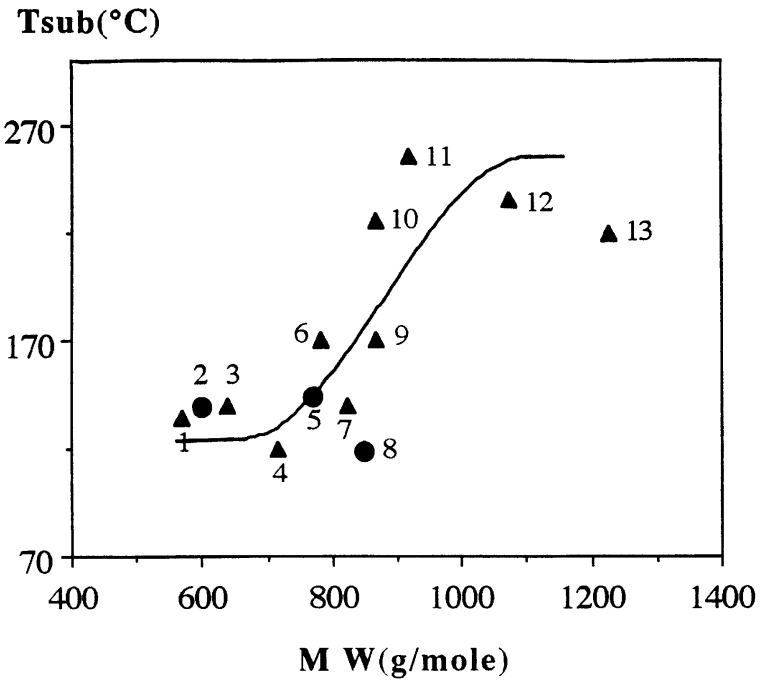

Figure 3 Sublimation temperatures of yttrium compounds, fluorinated (O) and non-fluorinated $(\boldsymbol{\Delta})$, as a function of molecular weight. 1, $\mathrm{Y}\left[\left(\mathrm{N}\left(\mathrm{SiMe}_{3}\right)_{2}\right]_{3},{ }^{67} \quad 2\right.$, $\left[\mathrm{Y}(\mathrm{ORf})_{3}\left(\mathrm{NH}_{3}\right)_{0.5}\right]{ }^{68} 3, \mathrm{Y}(\text { thd })_{3} ;{ }^{69} 4,\left[\mathrm{Y}(\mathrm{mpa})_{3}(\mathrm{bipy})\right] ; * *$ 5, $\left[\mathrm{Y}\left[\mathrm{OCMe}\left(\mathrm{CF}_{3}\right)_{2}\right]_{3}(\right.$ diglyme $\left.)\right] ;{ }^{68} \quad 6, \quad\left[\mathrm{Y}_{2}(\mathrm{OCMe} i \mathrm{Pr})_{6}\right] ;^{70} \quad 7$, $\mathrm{Y}\left[\mathrm{OSi}(t \mathrm{Bu})_{2}\left(\mathrm{CH}_{2}\right)_{3} \mathrm{NMe}_{2}\right]_{3},{ }^{71} 8,\left[\mathrm{Y}\left[\mathrm{OCMe}\left(\mathrm{CF}_{3}\right)_{2}\right]_{3}(\mathrm{THF})_{3}\right] ;{ }^{72}$ $\left.9, \quad\left[\mathrm{Y}_{2}(\mathrm{OCMeEiPr})_{6}\right] ;{ }^{70} \quad 10, \quad\left[\mathrm{Y}_{2}\left(\mathrm{OCEt}_{3}\right)_{6}\right]\right]^{70} \quad 11$, $\left[\mathrm{Y}(\mathrm{OAr})_{3}(\mathrm{THF})_{3}\right] ;^{73} 12, \quad\left[\mathrm{Y}_{3}(\mathrm{O} t \mathrm{Bu})_{9}(t \mathrm{BuOH})_{2}\right] ;^{70} \quad 13$, $\left.\left[\mathrm{Y}_{5} \mathrm{O}(\mathrm{O} i \mathrm{Pr})_{13}\right]\right]^{74}$

achieved through fluorinated ligands, the superconducting properties of the layers are generally poor, even in the absence of fluoride contamination. The concept of the use of fluorinated ligands for improving volatility and mass-transport characteristics has thus not been pursued in our group.

\section{Relationships between volatility and molecular weight: predictive trends?}

The volatility of a compound results from contributions from many factors. Enthalpies of sublimation have not been reported and relative volatilities are therefore estimated on the basis of sublimation temperatures. These data are semiquantitative at best, especially regarding the different pressures at which these temperatures have been reported (usually $10^{-2}-10^{-3}$ Torr). Nevertheless, qualitative comparisons of volatility as a function of the ligands set around the metal could be instructive. Sublimation temperatures indicate that an increase in the bulkiness of the ligands does not always improve volatility. Attempts to find correlations between sublimation

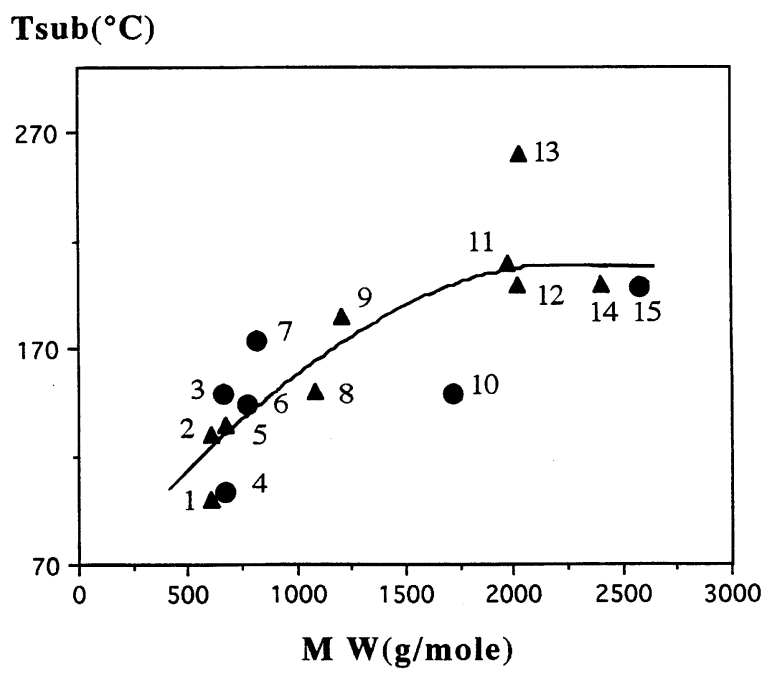

Figure 4 Sublimation temperatures of barium compounds, fluorinated ( $)$ and non-fluorinated $(\boldsymbol{\Delta})$, as a function of molecular weight. $1, \mathrm{Ba}\left[\mathrm{C}_{5} \mathrm{H}\left(i \mathrm{Pr}_{4}\right)_{4}\right]_{2} ;{ }^{39} 2, \mathrm{Ba}($ thd $)\left(\mathrm{OR}_{n}^{\prime}\right)\left(\mathrm{R}_{N}^{\prime} \mathrm{OH}\right)$ (H. Guillon and L.G. Hubert-Pfalzgraf, unpublished results); 3, $\left[\mathrm{Ba}(\mathrm{tfa})_{2}\right.$ (tetraglyme) $] ;^{32,33} \quad 4, \quad\left[\mathrm{Ba}(\mathrm{tfa})_{2}\left(\mathrm{Me}_{2} \mathrm{NC}_{2} \mathrm{H}_{4}{ }^{-}\right.\right.$ $\left.\left.\mathrm{NMeC}_{2} \mathrm{H}_{4} \mathrm{NMeC}_{2} \mathrm{H}_{4} \mathrm{NMe}_{2}\right)\right] ;^{75}$, [Ba(thd) $)_{2}\left(\mathrm{Me}_{2} \mathrm{NC}_{2} \mathrm{H}_{4} \mathrm{NMe}-\right.$ $\left.\left.\mathrm{C}_{2} \mathrm{H}_{4} \mathrm{NMe}_{2}\right)\right] ;^{29,30} 6$, [Ba(hfa) ${ }_{2}$ (tetraglyme) $;^{32,33} 7$, [Ba(hfa $)_{2}\left(18\right.$-crown-6)]; 76,77 $\left.8,{ }^{2} \mathrm{Ba}_{2}\left(\mathrm{OC} t \mathrm{Bu}\left(\mathrm{CH}_{2} \mathrm{OEt}\right)_{2}\right)_{4}\right] ;{ }^{46,47} 9$, $\left[\mathrm{Ba}_{2}\left(\mathrm{OCt} \mathrm{Bu}\left(\mathrm{CH}_{2} \mathrm{OiPr}\right)_{2}\right)_{4}\right] ;{ }^{46,47} 10,\left[\mathrm{Y}_{2} \mathrm{Ba}(\mathrm{ORf})_{4}(\mathrm{thd})_{4}\right] ;{ }^{65} 11$, $\left.\left.\left[\mathrm{Ba}_{2} \text { (thd }\right)_{4}(\mathrm{ArOH})_{4}(\mathrm{THF})_{2}\right]\right]^{78} 12,\left[\mathrm{Ba}_{4}(\mathrm{thd})_{8}\right] ; 13,\left[\mathrm{Ba}_{5}(\mathrm{OH})-\right.$ $\left.\left(\mathrm{OR}_{\mathrm{N}}\right)_{4}(\text { thd })_{5}\right] ;{ }^{49} 14,\left[\mathrm{Ba}_{5}(\mathrm{OH})(\text { thd })_{9}\left(\mathrm{H}_{2} \mathrm{O}\right)_{3}\right] ;{ }^{19} 15,\left[\mathrm{Ba}_{5}(\mathrm{OH})-\right.$ $\left.(\mathrm{ORf})_{9}(\mathrm{THF})_{4}\left(\mathrm{H}_{2} \mathrm{O}\right)\right]^{43}$

temperature and molecular weight were made for yttrium and barium derivatives.

Figure 3 summarizes the results for yttrium compounds. One can notice the high sublimation temperature of the aryl oxide $\left[\mathrm{Y}_{(}\left(\mathrm{OC}_{6} \mathrm{H}_{3}(t \mathrm{Bu})_{2}\right.\right.$ $\left.2,6)_{3}(\mathrm{THF})_{3}\right] \quad\left(255^{\circ} \mathrm{C} / 10^{-3}\right.$ Torr $)$. Its monomeric character has been achieved at the price of a high molecular weight and the species is thus less volatile than dinuclear ones. The figure also suggests that species having molecular weights around 600-700 Da $\left(\mathrm{g} \mathrm{mol}^{-1}\right)$ should display high volatility. The effect of fluorinated ligands can be seen with $\mathrm{Y}\left[\mathrm{OCMe}\left(\mathrm{CF}_{3}\right)_{2}\right]_{3}(\mathrm{THF})_{3}$, which sublimes at $120{ }^{\circ} \mathrm{C} / 10^{-2}$ Torr. The monomeric, ligandfree trimethylsilylamide $\mathrm{Y}\left[\mathrm{N}\left(\mathrm{SiMe}_{3}\right)_{2}\right]_{3}$ is highly volatile but also very moisture-sensitive. Figure 4 summarizes the data for barium derivatives. Although the representative points are quite scattered, the highest volatility according to sublimation temperatures seems to be obtained for molecular weights covering the range 700$1000 \mathrm{Da}$. The $\left[\mathrm{Ba}_{4}(\text { thd })_{8}\right]$ or $\mathrm{Ba}_{5}(\mathrm{OH})(\text { thd })_{9}\left(\mathrm{H}_{2} \mathrm{O}\right)_{3}$ 
Table 1 Requirements for MOCVD precursors (for thermal and aerosol-assisted CVD)

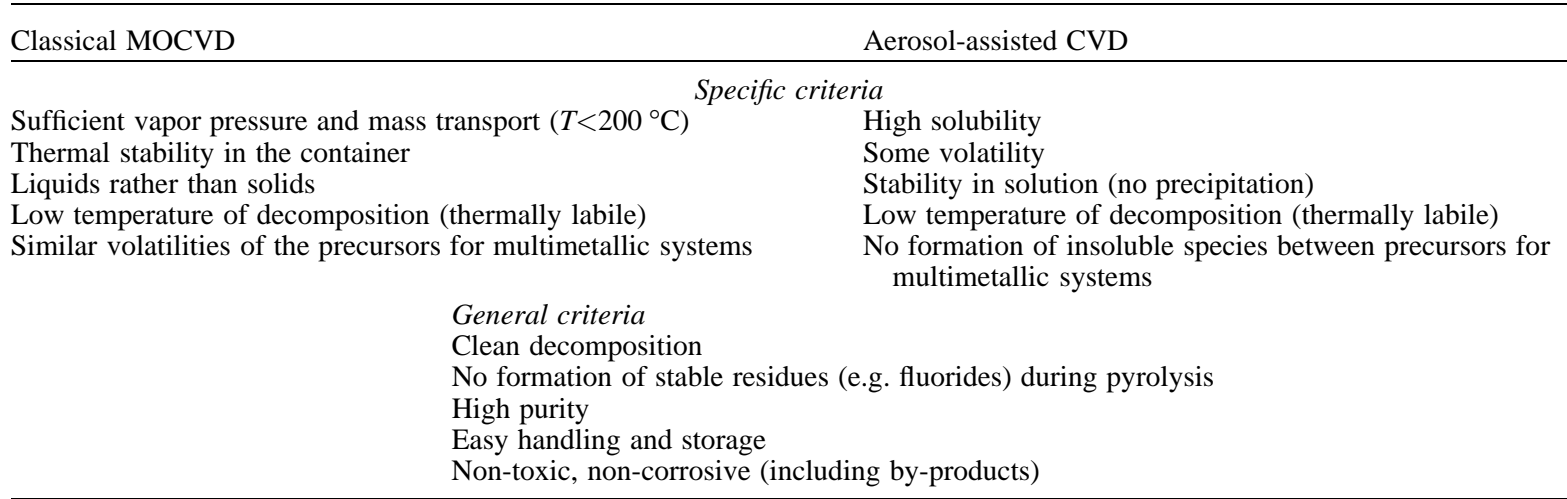

oligomers have quite high molecular weights $(>2000 \mathrm{Da})$ and a number of more volatile derivatives based on trifunctional alcohols have been reported, such as $\left[\mathrm{Ba}(\right.$ thd $\left.)\left(\mathrm{OR}^{\prime} \mathrm{N}\right)\left(\mathrm{R}^{\prime} \mathrm{NOH}\right)\right]$. (H. Guillon and L.G. Hubert-Pfalzgraf, unpublished results) However, the barium derivatives having low temperatures of sublimation are quite moisturesensitive or susceptible to dissociation. The use of the oligomers represents a compromise in terms of absence of fluoride contamination and easy handling.

\section{AACVD PRECURSORS}

\section{Requirements of precursors and solvents}

Dissolution of solid precursors in an appropriate solvent can be an alternative to the limitations described above. Different approaches for their transport into the evaporation chamber can be envisioned. They include mainly direct injection, spray pyrolysis or aerosols obtained via ultrasonic nebulization. Criteria for the selection of solvents for the nebulization process are high solubility of the precursors, low vapor pressure and low viscosity. Various alcohols or acetylacetone have often been used. ${ }^{79}$ Diethylene glycol dimethyl ether, $\mathrm{Me}\left(\mathrm{OC}_{2} \mathrm{H}_{4}\right)_{2} \mathrm{OMe}$ (diglyme, boiling point $160{ }^{\circ} \mathrm{C}$ ) or other glymes are also of interest. The solvent is an undesirable ballast in a CVD process. Therefore it should contain few carbon atoms, the partial pressure of the carbon dioxide generated by the decomposition of the solvent and/or precursors being generally the limiting factor for the growth rates of the films.

(C) 1998 John Wiley \& Sons, Ltd.
Solubility thus becomes a critical issue whereas volatility is the most important one for classical MOCVD. Compounds with poor volatility such as acetates have been used as precursors for AACVD experiments. Stability remains an important point but covers aspects different from those of conventional MOCVD. The precursor solutions are maintained at room temperature during the process but evolution of the solubility properties and precipitation can occur, especially during storage, as a result of impurities (hydrolysis generated by trace amounts of water) or by reactions if different types of precursors are used for multicomponent systems. These reactions, namely ligand exchange reactions or formation of mixed metal species, can occur if metal alkoxides are associated with $\beta$-diketonates or carboxylates in the feed solution and the homogeneity of the system can be modified Table 1 compares the requirements of precursors for classical MOCVD and for AACVD. Readily synthesized, low-cost chemicals, which can be manipulated on open benches, are also an important objective.

\section{Design of precursors for liquid- delivery techniques}

How can the quest for solubility and long-term stability in solution be addressed? By contrast to metal alkoxides, $\beta$-diketonates of different metals do not form stable mixed-metal species (although redistribution reactions between $\beta$-diketonates based on different ligands are observed in the vapor $)^{80,81}$ and therefore solubility properties cannot be modified.

$\beta$-Diketonates are, at first glance, also attractive precursors for aerosol-assisted MOCVD techniques. They are easy to handle by comparison 
with other metal oxide precursors such as metal alkoxides and they are reasonably soluble in organic solvents. Barium and yttrium tetramethylheptanedionates form complexes with polar solvents such as alcohols or glymes. ${ }^{27} \mathrm{Y}(\mathrm{thd})_{3}(\mathrm{iPr} \mathrm{OH})$ and $\left[\mathrm{Y}_{2}(\text { thd })_{6}(\right.$ triglyme $\left.)\right]$ have been reported, for instance. ${ }^{82,83} \mathrm{Cu}$ (thd) $)_{2}$, by contrast, is a poor Lewis acid and does not form stable complexes (the first $\mathrm{Cu}(\text { thd })_{2}$ complex stable in the vapor (with $o$-phen as a ligand) has only been reported very recently). Its solubility is also lower than that of the yttrium and barium derivatives and it is more soluble in solvents such as hexane and THF than in polar ones such as alcohols or glymes. These solvents are often used for AACVD because of their low vapor pressure. The amount of solvent necessary for access to high- $T_{\mathrm{c}}$ superconductors is thus generally determined by the solubility of $\mathrm{Cu}(\text { thd })_{2}$. An additional unfavorable feature is that the formulations require the largest amount of precursor for copper. Stability of the solutions is determined by the handling of the precursors and by the purity of the solvent used. The compounds are in general more moisture-sensitive in solutions than in the solid state. Although $\mathrm{Y}(\text { thd })_{3}$ is hygroscopic, giving $\mathrm{Y}(\mathrm{thd})_{3}\left(\mathrm{H}_{2} \mathrm{O}\right)$ on exposure to air, ${ }^{69}$ the demand lies essentially on the barium derivatives, which are more hydrolyzable than the other $\beta$-diketonates involved in the preparation of $\mathrm{YBa}_{2} \mathrm{Cu}_{3} \mathrm{O}_{7-x}$.

The importance of copper thin-film growth has motivated the synthesis of numerous $\mathrm{Cu}$ (II) ${ }^{85}$ and $\mathrm{Cu}(\mathrm{I})^{86}$ derivatives. Alkoxides supported by functional $\mathrm{R}$ groups such as copper(II) dimethylaminoethoxide $\left[\mathrm{Cu}\left(\mathrm{OC}_{2} \mathrm{H}_{4} \mathrm{NMe}_{2}\right)_{2}\right]$ are highly soluble as well as volatile; their drawback is their sensitivity, however. Rigorous anaerobic conditions are required. A large variety of copper(II) $\beta$-diketonatoalkoxides are known. ${ }^{87,88}$ They are dimeric or tetranuclear, and their solubility and volatility can be tuned by the nature of the OR group. However, these compounds are still air-sensitive, although less so than the homoleptic copper alkoxides of low nuclearity.

Barium tetramethylheptanedionate complexes can be used as a source of barium oxide for liquid-delivery techniques. Since volatility is not crucial for AACVD, the choice of the Lewis base will depend on its ability to encapsulate the metal for easy handling and storage of the precursor, and to form carbon-free deposits with superconducting properties. Polydentate ethers or polyamine ligands such as di- or tri-glymes, 2,2'-bipyridyl (bipy) or 1,10 -phenanthroline (o-phen) can for instance be selected. These complexes are all air-stable.
Although they dissociate during sublimation or in diglyme $\left({ }^{1} \mathrm{H}\right.$ NMR evidence), they are interesting alternatives to $\left[\mathrm{Ba}_{4}(\text { thd })_{8}\right]$ in terms of handling, the chelating Lewis bases precluding facile coordination of water and/or other reactants. $\left[\mathrm{Ba}_{2}(\text { thd })_{4}(\text { bipy })_{2}\right]$ is however a better choice than $\left.[\mathrm{Ba} \text { (thd })_{2}(o \text {-phen })_{2}\right]$ in terms of solubility and properties of the coatings. Use of commercial, non-distilled diglyme (containing dioxygen) leads rapidly to insoluble barium species if $\left[\mathrm{Ba}_{4}(\text { thd })_{8}\right]$ is used, thus modifying the composition (stoichiometry) of the feed solution, and to barium peroxo species. ${ }^{24,25}$ Better stability toward hydrolysis is observed with $\mathrm{Ba}$ (thd $)_{2}$ complexes where barium displays higher coordination numbers. $\left[\mathrm{Ba}_{5}(\mathrm{OH})(\text { thd })_{9}\left(\mathrm{H}_{2} \mathrm{O}\right)_{3}\right]$, a precursor in which the metals are assembled via a $\mu 5$-hydroxo ligand, appears to be quite stable toward peroxide formation.

\section{$\beta$-Ketoesterates}

Whereas functional alcohols or carboxylic acids are easily accessible, $\beta$-diketones with a donor appendage are of less practical use since they often require several steps for their synthesis. Moreover, intermolecular rather than intramolecular binding of the side chain bearing the Lewis base site polyether so far, can destroy the expected volatility and also limit the solubility of the compounds. ${ }^{89} \beta$ Ketoesters $\mathrm{ROCCH}_{2} \mathrm{CO}\left(\mathrm{OR}^{\prime}\right)$ are more easily accessible and the $\mathrm{OR}^{\prime}$ group could be a handle for tuning solubility, stability and volatility. Such ligands $\left(\mathrm{R}=\mathrm{Me}\right.$ and $\mathrm{R}^{\prime}=\mathrm{Me}, \mathrm{Et}, t \mathrm{Bu}, \mathrm{C}_{2} \mathrm{H}_{4} \mathrm{OMe}$ and $\mathrm{CH}_{2} \mathrm{C}_{6} \mathrm{H}_{5}$ ) were recently used for the development of copper precursors with low decomposition temperatures. ${ }^{90}$ We have selected methylpivaloylacetate (mpaH, $\left.\mathrm{R}=t \mathrm{Bu}, \mathrm{R}^{\prime}=\mathrm{Me}\right)$ as a ligand. ${ }^{91}$ $\mathrm{Cu}(\mathrm{mpa})_{2}$ was easily obtained by ligand exchange reactions using copper methoxide. The compound is volatile, air-stable and more soluble in diglyme - about three times more - than $\mathrm{Cu}(\text { thd })_{2}$. At first glance, $\mathrm{Cu}(\mathrm{mpa})_{2}$ could be a satisfactory alternative to $\mathrm{Cu}$ (thd $)_{2}$. However, ligand redistribution reactions between $\mathrm{Cu}(\mathrm{mpa})_{2}$ and yttrium or barium tetramethylheptanedionates are observed in diglyme at room temperature. $\mathrm{Cu}(\text { thd })_{2}$ is obtained after only about $30 \mathrm{~min}$ (UV evidence, Fig. 5) for solutions having the compositions required for the $\mathrm{YBa}_{2} \mathrm{Cu}_{3} \mathrm{O}_{7-x}$ ceramic. Tetramethylheptanedionates and $\beta$-ketoesterates are thus not compatible with each other if copper is involved. This can be overcome either by use of several 'source reactors' or by use of precursors from the same familly. The 


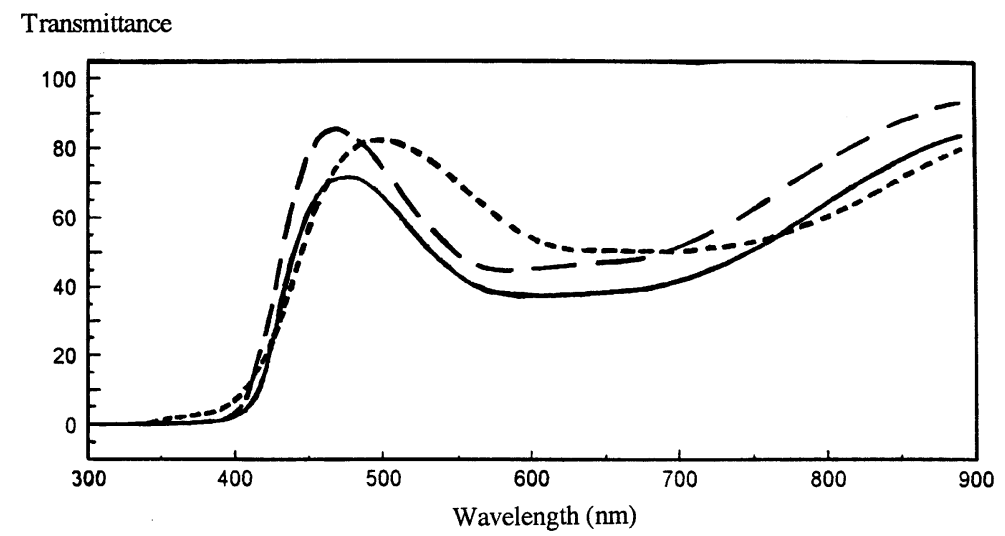

Figure 5 UV-visible spectra of $\mathrm{Cu}(\mathrm{mpa})_{2}(-), \mathrm{Cu}(\text { thd })_{2}(--)$ and $\mathrm{Cu}(\mathrm{mpa})_{2}$ mixed with $\mathrm{Ba}(\text { thd })_{2}$ after 30 min (-) (all spectra in diglyme with a copper concentration of $10^{-2} \mathrm{~mol}^{-1}$.

yttrium, cerium(IV) and barium methylpivaloylacetates were thus synthesized. They are obtained in high yields ( $>90 \%$ ) (Scheme 2). Their solubility is a function of the solvent. As observed for copper, their solubility is higher than that of the tetramethylheptanedionates in polar media. The yttrium and barium derivatives are however less soluble than the $\mathrm{M}(\text { thd })_{n}$ derivatives in hydrocarbons. The oligomeric nature of barium and yttrium methylpivaloylacetates can be reduced by the formation of complexes such as $\left[\mathrm{Y}(\mathrm{mpa})_{3}(\right.$ bipy $\left.)\right],\left[\mathrm{Ba}_{2}(\mathrm{mpa})_{4}{ }^{-}\right.$ (diglyme) $]$ or $\left[\mathrm{Ba}(\mathrm{mpa})_{2}(\mathrm{TMEDA})_{2}\right]$, for instance. The bipyridyl ligand was selected in order to adjust the molecular weight according to the trends observed for Fig. 3. [Y(mpa) $)_{3}$ (bipy)] sublimes without dissociation. Its sublimation temperature $\left(125^{\circ} \mathrm{C} / 10^{-3}\right.$ Torr $)$ is in agreement with the value expected, thus confirming that some prediction is possible. $\mathrm{Ce}(\mathrm{mpa})_{4}$ displays a volatility comparable with that of $\mathrm{Ce}$ (thd) $)_{4}$, but more residues are observed in the ambient-pressure TGA experiment. The formation of $\left[\mathrm{Ba}(\mathrm{mpa})_{2}\right]_{m}$ complexes is also a means of increasing stability toward moisture and thus of improving storage and handling. The main characteristics of the various $\beta$-ketoesterates are summarized in Table 2. Evaluation of their potential for obtaining films is in progress.

\section{Mixed-metal species vs heteroleptic species}

The mixing of different types of precursors, for

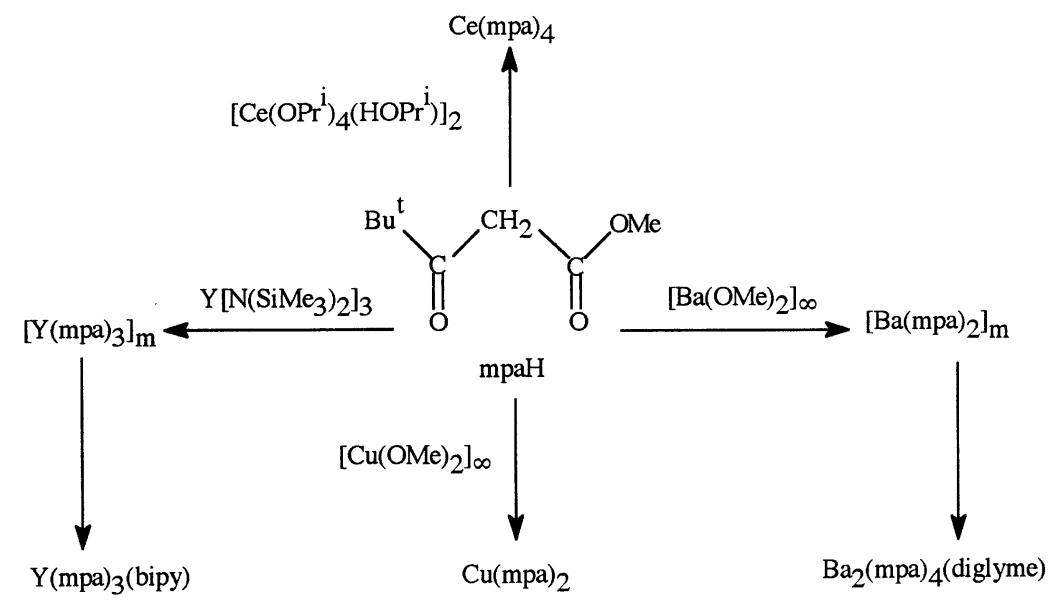

Scheme 2. Syntheses of $\beta$-ketoesterates (all reactions at room temperature in hexane). 
Table 2 Characteristics of $\beta$-ketoesterate derivatives

\begin{tabular}{|c|c|c|c|c|c|}
\hline Compound & $\begin{array}{l}\text { Melting point } \\
\left({ }^{\circ} \mathrm{C}\right)\end{array}$ & $\begin{array}{c}\text { Sublimation }^{\mathrm{a}} \\
\left({ }^{\circ} \mathrm{C} / \mathrm{T} \text { orr }\right)\end{array}$ & $\begin{array}{l}\text { Decomposition } \\
\text { temp. }\left({ }^{\circ} \mathrm{C}\right)\end{array}$ & Solubility $^{\mathrm{b}}$ & IR: $v(\mathrm{CO})\left(\mathrm{cm}^{-1}\right)^{\mathrm{c}}$ \\
\hline$\left[\mathrm{Ba}(\mathrm{mpa})_{2}\right]_{m}$ & $215-220$ & nv & 230 & $\begin{array}{l}\text { vs: THF, diglyme } \\
\text { s: toluene } \\
\text { ss: hexane }\end{array}$ & 1625,1594 \\
\hline $\mathrm{Ba}_{2}(\mathrm{mpa})_{4}($ diglyme $)$ & $130-135$ & nv & $210-215$ & $\begin{array}{l}\text { vs: THF, diglyme } \\
\text { s: toluene } \\
\text { ss: hexane }\end{array}$ & $1651,1643,1602,1592$ \\
\hline$\left[\mathrm{Y}(\mathrm{mpa})_{3}\right]_{m}$ & $120-125$ & nv & $215-220$ & $\begin{array}{l}\text { vs: THF, diglyme } \\
\text { s: toluene }\end{array}$ & $1624,1591,1548,1534$ \\
\hline $\mathrm{Y}(\mathrm{mpa})_{3}($ bipy $)$ & $195-200$ & $\begin{array}{l}120-125 / \\
2 \times 10^{-3}\end{array}$ & $225-230$ & $\begin{array}{l}\text { ss: hexane } \\
\text { vs: THF, diglyme } \\
\text { s: toluene } \\
\text { ss: hexane }\end{array}$ & $1647,1620,1576,1585^{\mathrm{d}}$ \\
\hline $\mathrm{Ce}(\mathrm{mpa})_{4}$ & 130 & $110 / 10^{-3}$ & $220-250$ & $\begin{array}{c}\text { vs: hexane, toluene, } \\
\text { THF }\end{array}$ & 1619,1593 \\
\hline $\mathrm{Cu}(\mathrm{mpa})_{2}$ & $110-115$ & $55-60 / 10^{-3}$ & $220-225$ & $\begin{array}{c}\text { vs: hexane, toluene, } \\
\text { THF }\end{array}$ & $1754 \mathrm{~s}, 1709 \mathrm{~s}, 1653 \mathrm{~m}, 1620 \mathrm{~m}$ \\
\hline
\end{tabular}

${ }^{\mathrm{a}}$ nv, not volatile under $10^{-3}$ Torr and heated to $230^{\circ} \mathrm{C}$.

b vs, very soluble; ss, sparingly soluble.

c $v(\mathrm{CO})(\mathrm{mpaH}): 1754 \mathrm{~s}, 1709 \mathrm{~s}, 1653 \mathrm{~m}, 1620 \mathrm{~m} \mathrm{~cm}^{-1}$.

d And $v(\mathrm{C}=\mathrm{N})$.

instance metal alkoxides and $\beta$-diketonates, results generally in the formation of new species as a result of the lability of the M-OR bond. These species can be either homometallic heteroleptic ones such as $\mathrm{M}(\mathrm{OR})_{n-x}(\beta \text {-dik })_{x}$ or heterometallic ones. ${ }^{28}$ Formation of mixed-metal species can be exploited for the increase in solubility, in the stability toward moisture and/or dioxygen, and, if the right set of ligands has been selected as we have seen previously, in the volatility. ${ }^{65}$ However, if $\beta$-diketonate ligands are a means of increasing volatility, they can also favor segregation between the metals in solution. The use of THF acting as a monodendate Lewis base can be sufficient for dissociation and formation of homometallic species in the case of OR groups such as $t$-butoxide, ${ }^{28}$ especially if copper is one of the metals. Compounds based on functional alcohols are more stable toward dissociation.

Functional alkoxide ligands have been largely used for sol-gel applications in order to increase solubility and to decrease the susceptibility toward water. ${ }^{2}$ Alkoxyalkoxides $\mathrm{OC}_{2} \mathrm{H}_{4} \mathrm{OR}$ are prone to bridging-chelating coordination modes and thus to increase the nuclearity and molecular weight of the precursor. Aminoalkoxide ligands such as $\mathrm{OC}_{2} \mathrm{H}_{4} \mathrm{NMe}_{2}$ seem more favorable for attaining volatility and a low nuclearity. This is well illustrated in the case of copper by the formation of an oligomeric, insoluble and non-volatile $\left[\mathrm{Cu}\left(\mathrm{OC}_{2} \mathrm{H}_{4} \mathrm{OMe}\right)_{2}\right]_{m} \quad$ species, whereas $\left[\mathrm{Cu}\left(\mathrm{OC}_{2} \mathrm{H}_{4} \mathrm{NMe}_{2}\right)_{2}\right]$ is monomeric and volatile. No volatility was reported so far for heterometallic derivatives based on alkoxyalcohols such as 2methoxyethoxide as an assembling ligand. ${ }^{59,60,63}$ Aminoalcohols can be another means of linking metals together.

Reactions between $\beta$-diketonates and metal alkoxides supported by aminoalcohols were thus investigated. Subtle differences in the OR group can lead to a different course of reaction (Scheme 3). This is well illustrated by the $\mathrm{Y}-\mathrm{Cu}$ and $\mathrm{Pr}-\mathrm{Cu}$

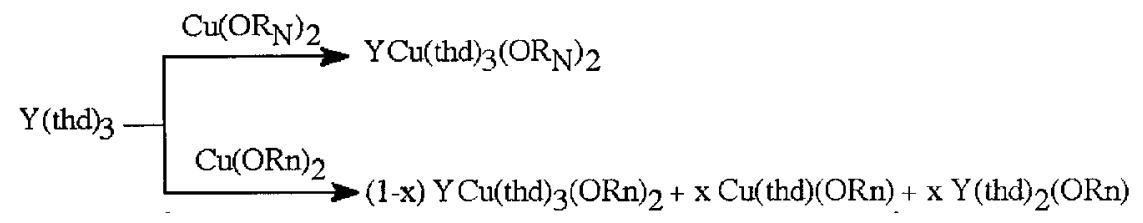

Scheme 3 Alternative reactions between $\mathrm{Y}(\mathrm{thd})_{3}$ and copper alkoxides (see text). 


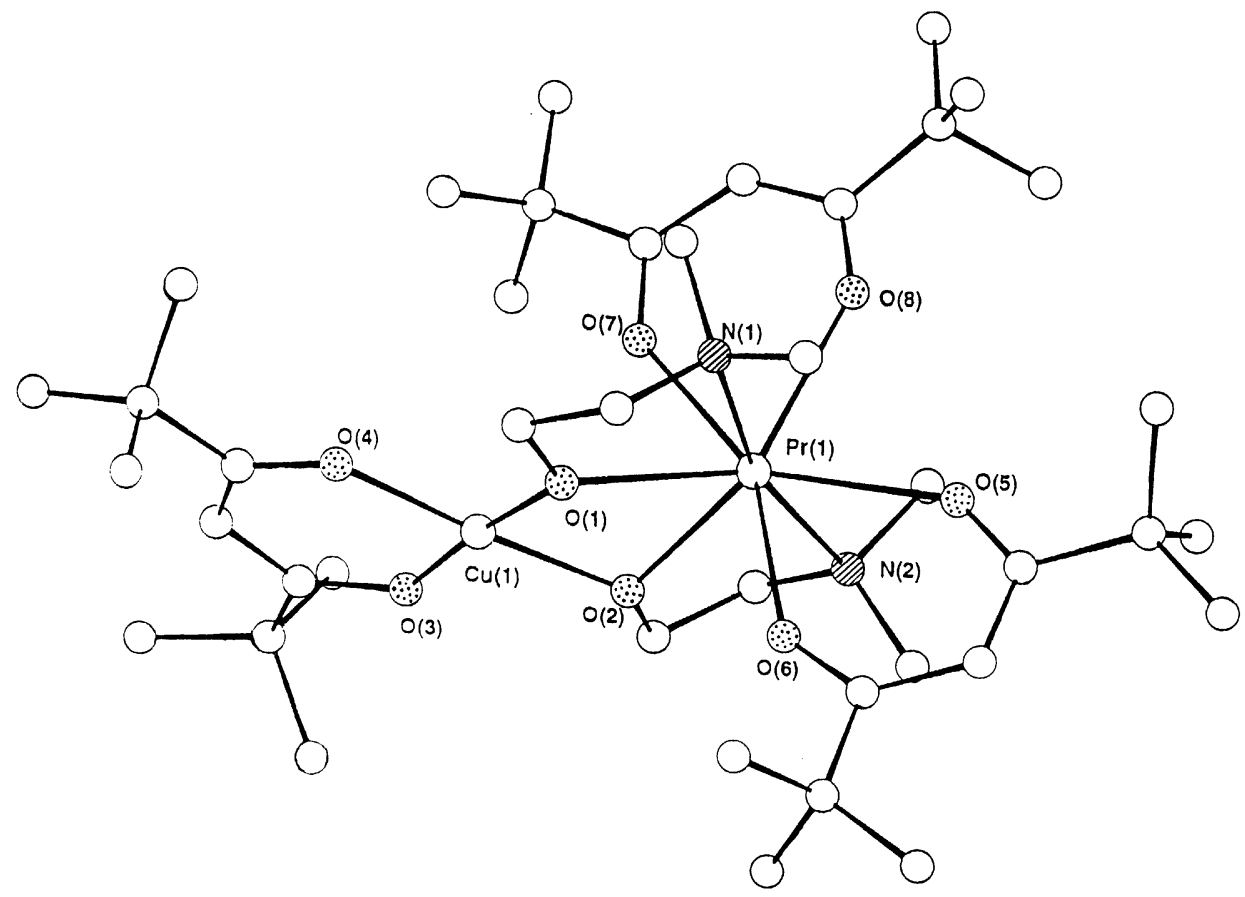

Figure 6 Molecular structure of $\mathrm{PrCu}(\mathrm{thd})_{3}(\mathrm{ORn})_{2}$.

systems. The mixing of $\mathrm{Y}(\text { thd })_{3}$ and $\mathrm{Cu}(\mathrm{OCH}-$ $\left.\mathrm{MeCH}_{2} \mathrm{NMe}_{2}\right)_{2}$ provides a single species by selfassembly. Changing the alkoxide to $\mathrm{Cu}\left(\mathrm{OC}_{2} \mathrm{H}_{4} \mathrm{NMe}_{2}\right)_{2}$ leads to a more complex solution with formation of a mixed-metal species as well as of yttrium and copper $\beta$-diketonatoalkoxides resulting from redistribution reactions.

$\mathrm{YCu}(\text { thd })_{3}\left(\mathrm{OR}_{\mathrm{N}}\right)_{2}$ is volatile, but less so than $\mathrm{Y}(\mathrm{thd})_{3}$. Two mixed-metal species of different stoichiometry (1:1 and 1:2) have been isolated for the $\mathrm{Pr}-\mathrm{Cu}$ system (praseodymium derivatives are of interest for heteroepitaxy applications). The copper-rich species $\mathrm{PrCu}_{2}(\text { thd })_{3}(\mathrm{ORn})_{4}$ sublimes $\left(140^{\circ} \mathrm{C} / 10^{-4}\right.$ Torr) with liberation of copper alkoxide giving the more stable $\mathrm{PrCu}(\text { thd })_{3}(\mathrm{ORn})_{2}$ species. Its structure has been established by singlecrystal X-ray diffraction (Fig. 6). The aminoalcohol acts as an assembling $\mu, \eta^{2}$-ligand. The nitrogen donor sites interact with the lanthanide, allowing the metal to be eight-coordinate. The diketonate ligands are terminal and chelating. A benefit of these heterometallic species is their stability toward moisture by comparison with the hygroscopic nature of $\mathrm{Y}(\mathrm{thd})_{3}$ or $\left[\mathrm{Pr}_{2}(\text { thd })_{6}\right]$ and the hydrolyzable character of the copper alkoxides. The mixing of an appropriate set of precursors can thus be a means of enhancing the stability of the metallic species. The volatility of the $\mathrm{MCu}(\text { thd })_{3}(\mathrm{OCH}-$ $\left.\mathrm{MeCH}_{2} \mathrm{NMe}_{2}\right)_{2}(\mathrm{M}=\mathrm{Pr}, \mathrm{Y})$ species (sublimation $130{ }^{\circ} \mathrm{C} / 10^{-4}$ Torr and $150{ }^{\circ} \mathrm{C} / 10^{-4}$ Torr respectively) is also compatible with their use as precursors for conventional CVD. These compounds represent, to the best of our knowledge, the first examples of volatile and structurally characterized mixed-metal $\beta$-diketonatoalkoxides not supported by fluoroalkoxide ligands.

Sterically encumbered aryl oxide ligands are another means of reducing the hydrolytic susceptibility of the precursors. An aryl oxide with potentially chelating aminomethyl arms could also act as an efficient bridging 'pincer' ligand. Stable hydrates have for instance been isolated for praseodymium. $^{92,93}$ The potential of the 2,4,6tris(dimethylaminomethyl)phenoxy ligand (Otamp) has thus been explored. The reaction between $\left[\mathrm{Ba}_{4} \mathrm{O}(\mathrm{Otamp})_{6}\right]^{94}$ and copper tetramethylheptanedionate (4 equiv) in hexane affords $\left[\mathrm{BaCu}(\text { thd })_{2}\right.$ (Otamp $\left.)_{2}\left(\mathrm{H}_{2} \mathrm{O}\right)\right]$, as shown by X-ray diffraction (Fig. 7). The same species is obtained from $\mathrm{Cu}(\text { Otamp })_{2}$ and $\left[\mathrm{Ba}_{4}(\text { thd })_{8}\right]$. The presence of water favors the isolation of $\left[\mathrm{BaCu}(\text { thd })_{2}(\mathrm{Otamp})_{2}\left(\mathrm{H}_{2} \mathrm{O}\right)\right]$ in high yield $(90 \%)$ but is not necessary for the formation of a $\mathrm{Ba}-\mathrm{Cu}$ derivative. $\left[\mathrm{BaCu}(\text { thd })_{2}\right.$ $\left.(\text { Otamp })_{2}\left(\mathrm{H}_{2} \mathrm{O}\right)\right]$ is soluble in diglyme; no dissocia- 


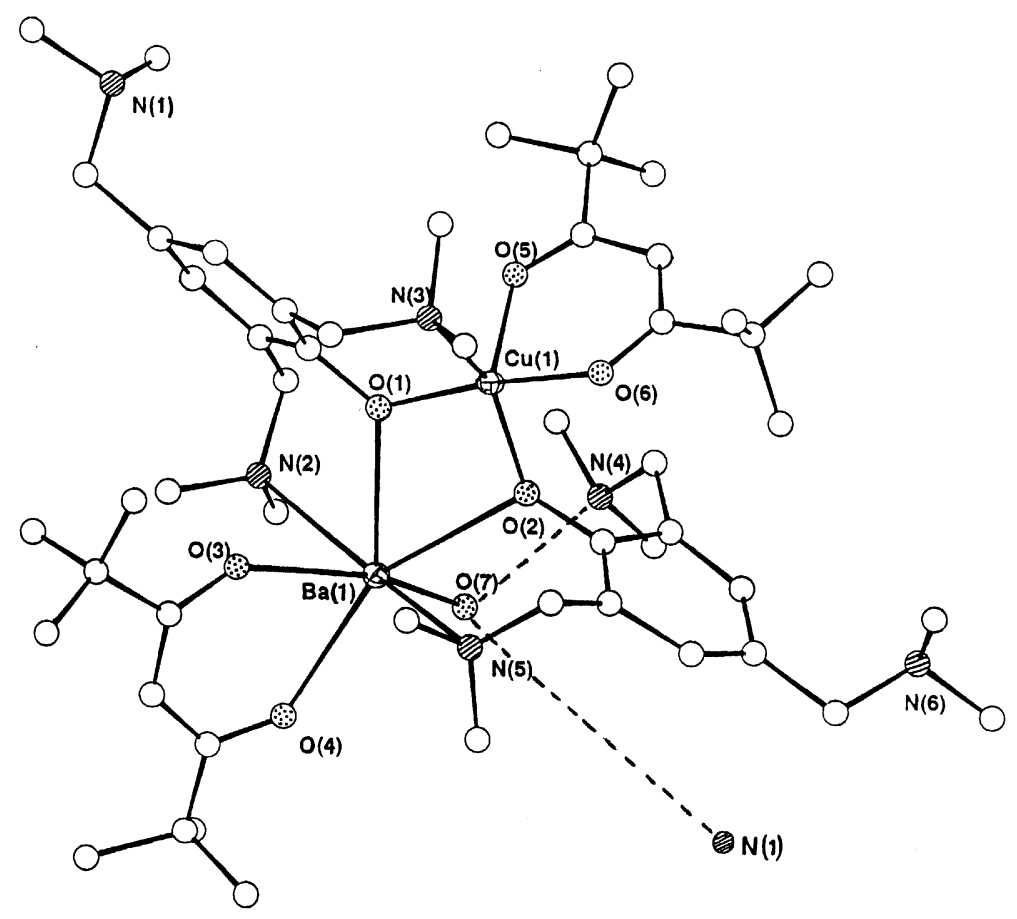

Figure 7 Molecular structure of $\left[\mathrm{BaCu}(\text { thd })_{2}\left(\mu, \eta^{2}\right.\right.$-Otamp $\left.)\left(\mathrm{H}_{2} \mathrm{O}\right)\right]$ (broken lines indicate hydrogen bonds).

tion and/or formation of a complex is observed (UV evidence). This can be explained by the molecular structure. Each metal bears a chelating tetramethylheptanedionate ligand, the aryl oxide ligands act as assembling moieties via the oxygen atom but the metals are also clamped together by the nitrogen donor functionalities. The $\mathrm{Ba}-\mathrm{N}(2)$ and $\mathrm{Cu}-\mathrm{N}(3)$ coordination bonds lead to a tridendate aryl oxide. The other aryl oxide is of the $\mu, \eta^{2}$ type and thus only one nitrogen center acts as a Lewis base. The water molecule is linked to barium but interacts by intra- and inter-molecular hydrogen bonding with the adjacent nitrogen sites. The barium atom is seven-coordinate and the copper center five-coordinate with a tetragonal-pyramidal surrounding. The steric crowding around barium makes the compound air-stable. The presence of hydrogen bonding is prejudicial to the volatility of the compound in the solid state. However, transport into the vapor via an aerosol can be achieved and evaluation of the characteristics of the deposits is in progress. Thermal decomposition starts at $\approx 195^{\circ} \mathrm{C}$, a temperature which is quite low for aryl oxide derivatives. Different behavior is observed in solution if copper acetylacetonate reacts with $\left[\mathrm{Ba}_{4} \mathrm{O}(\mathrm{Otamp})_{6}\right]$. These observations indicate the need for preliminary studies if different types of precursors are involved in a process.

Table 3 summarizes some characteristics of the novel homometallic and mixed-metal species as compared with the usual $\beta$-diketonate derivatives.

\section{CONCLUSIONS}

The survey of the volatility data (namely sublimation temperatures) reported in the literature shows that an optimal volatility can be predicted on the basis of molecular weight in the case of yttrium derivatives. This has been confirmed with a $\beta$ ketoesterate complex, Y (mpa)3(bipy). The situation is more complex for barium derivatives, probably as a result of the influence of dissociation reactions and of a poor knowledge of the true molecular formulae. The limited number of volatile $\mathrm{Ce}(\mathrm{IV})$ or $\mathrm{Ce}(\mathrm{III})$ derivatives known so far precludes predictive trends. Novel precursors are desirable.

AACVD requires highly soluble species but their hydrolytic susceptibility should be reduced, especially for technological applications. Steric satura- 
Table 3 Characteristics of some $\mathrm{Ba}, \mathrm{Cu}, \mathrm{Y}$ and $\mathrm{Ce}(\mathrm{IV})$ complexes

\begin{tabular}{|c|c|c|c|}
\hline Complex & Solubility in diglyme $\left(\mathrm{mol} \mathrm{l}^{-1}\right)$ & Sublimation $\left({ }^{\circ} \mathrm{C} /\right.$ Torr$)$ & Stability \\
\hline$\left[\mathrm{Ba}_{4}(\mathrm{thd})_{8}\right]$ & $1.35 \times 10^{-1}$ & $185-195 / 10^{-3}$ & Hygroscopic \\
\hline$\left[\mathrm{Ba}\left(\mathrm{OR}_{\mathrm{N}}^{\prime}\right)(\mathrm{thd})\left(\mathrm{R}_{\mathrm{N}}^{\prime} \mathrm{OH}\right)\right]^{52}$ & $8 \times 10^{-2}$ & $120-130 / 10^{-3}$ & Moisture-sensitive \\
\hline$\left[\mathrm{Ba}_{2}(\mathrm{mpa})_{4}(\right.$ diglyme $\left.)\right]$ & $8.5 \times 10^{-1}$ & Not volatile $^{\mathrm{a}}$ & Air-stable \\
\hline$\left[\mathrm{Ba}(\text { thd })_{2}(\text { phen })_{2}\right]$ & $3.8 \times 10^{-2}$ & Diss: $140 / 10^{-3}$ & Air-stable \\
\hline$\left[\mathrm{Ba}_{2}(\text { thd })_{4}(\text { bipy })_{2}\right]$ & $2.7 \times 10^{-1}$ & Diss:40-50/10 -3 & Air-stable \\
\hline $\mathrm{Cu}(\text { thd })_{2}$ & $8.1 \times 10^{-2}$ & $88-95 / 5 \times 10^{-2}$ & Air-stable \\
\hline $\mathrm{Cu}(\mathrm{mpa})_{2}$ & $2.3 \times 10^{-1}$ & $55-60 / 10^{-3}$ & Air-stable \\
\hline$\left[\mathrm{BaCu}(\mathrm{thd})_{2}(\mathrm{Otamp})_{2}\left(\mathrm{H}_{2} \mathrm{O}\right)\right]$ & $1.7 \times 10^{-1}$ & Not volatile* & Air-stable \\
\hline $\mathrm{PrCu}(\text { thd })_{3}(\mathrm{ORn})_{2}$ & $-\mathrm{b}$ & $155 / 10^{-4}$ & Air-stable \\
\hline $\mathrm{PrCu}(\text { thd })_{3}\left(\mathrm{OR}_{\mathrm{N}}\right)_{2}$ & $-\mathrm{b}$ & $130 / 10^{-4}$ & Air-stable \\
\hline $\mathrm{YCu}(\text { thd })_{3}\left(\mathrm{OR}_{\mathrm{N}}\right)_{2}$ & $-\mathrm{b}$ & $150 / 10^{-4}$ & Air-stable \\
\hline $\mathrm{Y}(\mathrm{thd})_{3}$ & $7 \times 10^{-1}$ & $140 / 5 \times 10^{-2}$ & Hygroscopic \\
\hline $\mathrm{Y}(\mathrm{mpa})_{3}$ & 1.25 & Not volatile $_{3}$ & Hygroscopic \\
\hline$\left[\mathrm{Y}(\mathrm{mpa})_{3}(\mathrm{bipy})\right]$ & $4.9 \times 10^{-1}$ & $120-125 / 10^{-3}$ & Air-stable \\
\hline $\mathrm{Ce}(\text { thd })_{4}$ & $1.5 \times 10^{-2}$ & $135-140 / 10^{-3}$ & Air-stable \\
\hline $\mathrm{Ce}(\mathrm{mpa})_{4}$ & $3 \times 10^{-1}$ & $100-110 / 3 \times 10^{-3}$ & Air-stable \\
\hline$\left[\mathrm{Ce}\left(\mathrm{OR}_{\mathrm{f}}\right)_{4}(\text { diglyme })\right]^{52}$ & $8 \times 10^{-1}$ & $70 / 10^{-3}$ & Moisture-sensitive \\
\hline
\end{tabular}

${ }^{a}$ Not volatile under $10^{-3}$ Torr and heated to $220^{\circ} \mathrm{C}$.

${ }^{b}$ Poorly soluble in diglyme but soluble in hexane, toluene and THF.

tion around the metal is a means of ensuring easy handling and protection against moisture and/or dioxygen. The selection of polar solvents because of their low vapor pressure is interesting since they might also ensure stabilization by complexation of the metal-containing species. For multimetallic systems likely to be based on the use of a single feed solution, the mixing of the same type of precursors is a guarantee of compatibility. Systems using different types of precursors might require immediate use, or additional studies of their molecular constitution to obtain information about their long-term stability regarding the absence of precipitation. Ligand exchange reactions are functions of numerous factors, among them the metal, and can occur even for derivatives as similar as $\beta$ diketonates and $\beta$-ketoesterates. Volatile, air-stable and soluble mixed-metal $\mathrm{Y}-\mathrm{Cu}$ and $\mathrm{Pr}-\mathrm{Cu} \beta$ diketonatoalkoxides in which the metals are linked together by aminoalkoxide ligands have been obtained. They represent the first examples of volatile lanthanide-copper species without fluorinated ligands; their physical properties are compatible with their use in conventional as well as aerosol-assisted CVD. Evaluation of these precursors is currently in progress. However, if some tailoring of stability and volatility is possible, a better understanding of the fundamentals of the growth process that involves a combination of gasphase and surface chemistry is required to give better predictions of characteristics such as purity or epitaxy, especially for multicomponent oxides.
Acknowledgment Part of this work was performed under the EEC grant BRE2-CT94-0742.

\section{REFERENCES}

1. S. T. Swartz and V. E. Wood, Condens Matter News 1, 4 (1992).

2. L. G. Hubert-Pfalzgraf, Appl. Organometal. Chem. 27, 627 (1992).

3. U. Schubert, N. Husing and A. Lorenz, Chem. Mater. 7, 2010 (1995).

4. R. E. Sievers, S. B. Turnipseed, L. Huang and A. F. Lagolante, Coord. Chem. Rev. 128, 285 (1993).

5. A. A. Drozdov and S. I. Troyanov, J. Phys. IV 5, 373 (1995).

6. M. Becht, K. H. Dahmen, V. Gramlich and A. Marteletti, Inorg. Chim. Acta 248, 27 (1996).

7. J. McAleese, J. C. Plakatouras and B. C. H. Steele, Thin Solid Films 280, 152 (1996).

8. T. Leskela, K. Vasama, G. Härkönen, P. Sarkio and M. Lounasmaa, Adv. Mater. Optics. Electron. 6, 169 (1996).

9. S. K. Dey and P. V. Alluri, MRS Bull. 21, 44 (1996).

10. B. N. Hansen, B. M. Hybertson, R. M. Barkley and R. E. Sievers, Chem. Mater. 4, 749 (1994).

11. A. Drozdov and S. Troyanov, Main Group Met. Chem. 19, 547 (1996).

12. N. W. Mitzel, S. Parsons, A. J. Blake and W. H. Rankin, J. Chem. Soc., Dalton Trans. 2089 (1996).

13. P. C. Buskirk, S. M. Bilodeau, J. F. Roeder and P. S. Kirlin, Jpn. J. Appl. Phys. 35, 2520 (1996).

14. S. H. Shamlian, M. L. Hitchman, S. K. Cook and B. C. Richards, J. Mater. Chem. 4, 81 (1994).

Appl. Organometal. Chem. 12, 221-236 (1998) 
15. M. L. Hitchman and D. D. Gilliland, Cerami. Int. 22, 515 (1996).

16. L. G. Hubert-Pfalzgraf, New J. Chem. 19, 727 (1995).

17. A. A. Drozdov and S. I. Troyanov, Polyhedron 11, 2877 (1992)

18. A. Gleizes, S. Sans Lenain and D. Médus, C. R. Acad. Sci. Paris, Série II 313, 761 (1991)

19. L. Huang, S. B. Turnipseed, R. Haltiwanger, R. M. Barkley and R. E. Sievers, Inorg. Chem. 33, 798 (1994).

20. A. A. Drozdov, S. I. Troyanov, A. P. Pisarevsky and Yu T. Struchkov, Polyhedron 13, 1445 (1994).

21. A. A. Drozdov and S. I. Troyanov, Polyhedron 11, 2877 (1992).

22. A. A. Drozdov, S. I. Troyanov, A. P. Pisarevsky and Yu. T. Struchkov, Polyhedron 13, 2459 (1995).

23. A. Gleizes, S. Sans-Lenain, D. Medus and R. Morancho, C.R. Acad. Sci. Paris, Série II 312, 983 (1991).

24. N. Hovnanian, J. Galloy and P. Miele, Polyhedron 14, 297 (1995).

25. J. Auld, A. C. Jones, A. B. Leese, B. Cockayne, P. J. Wright, P. O Brien and M. Motevalli, J. Mater. Chem. 3, 1203 (1993).

26. I. K. Igumenov, P. P. Semyannikov, S. V. Belaya, A. S. Zanina, S. I. Shergina and I. E. Sokolov, Polyhedron 15, 4521 (1996).

27. S. R. Drake, M. B. Hursthouse, K. M. Abdul Malik and S. A. S. Miller, Inorg. Chem. 32, 4653 (1993), and references therein.

28. F. Labrize, L. G. Hubert-Pfalzgraf, J. Vaissermann and C. B. Knobler, Polyhedron 15, 577 (1996), and references therein.

29. B. A. Vaartstra, R. A. Gardiner, D. C. Gordon, R. L. Ostrander and A. L. Rheingold, MRS Proc. 340, 37 (1994).

30. R. A. Gardiner, D. C. Gordon, G. T. Stauf and B. A. Vaartstra, Chem. Mater. 61967 (1994)

31. A. A. Drozdov, N. Kuzmina, S. I. Troyanov and L. Martynenko, Mater. Sci. Eng. B18, 139 (1993).

32. R. Gardiner, D. W. Brown, P. S. Kirlin and A. L. Rheingold, Chem. Mater. 3, 1053 (1991).

33. K. Timmer and H. A. Meimena, Inorg. Chim. Acta 187, 99 (1991).

34. D. A. Neumayer, D. B. Studebaker, B. J. Hinds, C. L. Stern and T. J. Marks, Chem. Mater. 6, 878 (1994).

35. A. A. Drozdov and S. I. Trojanov, J. Chem. Soc. Chem. Commun. 1619 (1993).

36. D. C. Bradley, M. Hasan, M. B. Hursthouse, M. Motevalli, O. F. Z. Khan, R. G. Pritchard and J. O. Williams, J. Chem. Soc., Chem. Commun. 576 (1992)

37. L. E. E. de Araujo, A. S. I. Gomes and C. B. Araujo, Phys. Rev. B 50, 16219 (1994)

38. A. Konishi, H. Izum, R. Kanno and Y. Kawamoto, J. Mater. Sci. 29, 1584 (1994).

39. T. P. Hanusa, Chem. Rev. 93, 1023 (1993).

40. S. R. Drake, M. B. Hursthouse, K. M. A. Malik and D. Otway, J. Chem. Soc., Dalton Trans. 2883 (1993).

41. M. P. Hogerheide, J. Boersma and G. Van Koten, Coord. Chem. Rev. 155, 87 (1996).

42. P. Miele, J. D. Foulon and N. Hovnanian, Polyhedron 12, 209 (1993).

C) 1998 John Wiley \& Sons, Ltd.
43. H. Vincent, F. Labrize and L. G. Hubert-Pfalzgraf, Polyhedron 13, 3323 (1994)

44. K. G. Caulton, M. H. Chisholm, S. R. Drake and J. C. Huffman, J. Chem. Soc., Chem. Commun. 1349 (1990).

45. K. F. Tesh, T. P. Hanusa, J. C. Huffman and C. J. Huffman, Inorg. Chem. 31, 5572 (1992), and references therein.

46. W. A. Herrmann, N. W. Huber and T. Priermeier, Angew. Chem. Int. Ed. Engl. 33, 105 (1994).

47. W. A. Herrmann, N. W. Huber and O. Runte, Angew. Chem., Int. Ed. Engl. 34, 2187 (1994).

48. V. C. Arunasalam, I. Baxter, S. R. Drake, M. B. Hursthouse, K. M. Abdul Malik and D. J. Otway, Inorg. Chem. 34, 5295 (1995).

49. L. G. Hubert-Pfalzgraf, F. Labrize, C. Bois and J. Vaissermann, Polyhedron 13, 2163 (1994).

50. K. G. Caulton, M. H. Chisholm, S. R. Drake and W. E. Streib, Angew. Chem., Int. Ed. Engl. 29, 1483 (1990).

51. W. A. Wojtczak, M. J. Hampden-Smith and E. N. Duesler, Inorg. Chem. 35, 6638 (1996).

52. W. A. Wojtczak, P. Atanassova, M. J. Hampden-Smith and E. N. Duesler, Inorg. Chem. 35, 6995 (1995).

53. D. A. Neumayer, D. B. Studebaker, B. J. Hinds, C. L. Stern and T. J. Marks, Chem. Mater. 6, 878 (1994).

54. T. R. Belderrain, L. Contreras, M. Paneque, E. Carmona, A. Monge and C. Ruiz, Polyhedron 15, 3453 (1996).

55. S. G. Dutremez, D. B. Leslie, W. E. Streib, M. H. Chisholm and K. G. Caulton, J. Organometal. Chem. 462, C1 (1993).

56. M. L. Hays, T. P. Hanusa and T. A. Nile, J. Organometal. Chem. 514, 73 (1996).

57. L. G. Hubert-Pfalzgraf, Polyhedron 13, 1181 (1994)

58. K. G. Caulton and L. G. Hubert-Pfalzgraf, Chem. Rev. 90, 969 (1990).

59. W. Bidell, H. W. Bosch, D. Veghini, H. U. Hund, J. Doring and H. Berke, Helv. Chim. Acta 76, 596 (1993).

60. W. Bidell, H. Skhlover and H. Berke, Inorg. Chem. 31, 5561 (1992).

61. P. Miele, J. D. Foulon, N. Hovnanian and L. Cot, J. Chem. Soc., Chem. Commun. 29 (1993).

62. S. N. Wang, Z. Pang, K. D. L. Smith, Y. S. Hua, C. Deslippe and M. J. Wagner, Inorg. Chem. 34, 908 (1995).

63. W. Bidell, J. Doring, H. W. Hund, E. Plappert and H. Berke, Inorg. Chem. 32, 502 (1993).

64. A. P. Purdy and C. F. George, Inorg. Chem. 30, 2812 (1991).

65. F. Labrize, L. G. Hubert-Pfalzgraf, J. C. Daran and P. Tobaly, Polyhedron 15, 2707 (1996).

66. G. Malandrino, F. Castelli and I. L. Fragalla, Inorg. Chim. Acta 224, 203 (1994).

67. D. C. Bradley, J. S. Ghotra and F. A. Hart, J. Chem. Soc., Chem. Commun. 1021 (1973).

68. D. C. Bradley, H. Chudzynska, M. B. Hursthouse and M. Motevalli, Polyhedron 12, 1907 (1993).

69. A. Gleizes, S. Sans-Lenain, D. Medus, N. Hovnanian, P. Miele and J. D. Foulon, Inorg. Chim. Acta 269, 47 (1993).

70. D. C. Bradley, H. Chudzynska, M. B. Hursthouse and M. Motevalli, Polyhedron 10, 1049 (1991).

71. P. Shao, D. J. Berg and G. W. Bushnell, Inorg. Chem. 33, 3452 (1994)

72. D. C. Bradley, H. Chudzynska, M. E. Hammond, M. B. 
Hursthouse, M. Motevalli and W. Ruowen, Polyhedron 11, 375 (1992).

73. P. B. Hitchcok, M. F. Lappert and R. G. Smith, Inorg. Chim. Acta 139, 183 (1987).

74. O. Poncelet, W. J. Sartain, L. G. Hubert-Pfalzgraf, K. Folting and K. G. Caulton, Inorg. Chem. 28, 163 (1989).

75. S. R. Drake, M. B. Hursthouse, K. M. A. Malik and S. A. S. Miller, Inorg. Chem. 32, 4464 (1993).

76. J. A. T. Norman and G. P. Pez, J. Chem. Soc., Chem. Commun. 971 (1991).

77. K. Timmer and H. A. Meimena, Inorg. Chim. Acta 187, 99 (1991).

78. P. Miele, J. D. Foulon and N. Hovnanian, Polyhedron 12, 209 (1993).

79. M. Langlet, D. Walz, P. Marage and J. C. Joubert, Thin Solid Films 221, 44 (1992).

80. C. Sant, O. Poncelet, M. Laugt, L. G. Hubert-Pfalzgraf, P. Gibart and C. Verié, Vide, Couches Minces 252, 205 (1990).

81. C. Sant, Ph.D. Thesis, University of Nice, 1992.

82. P. Miele, Ph.D. Thesis, University of Montpellier, 1993.

83. S. R. Drake, M. B. Hursthouse, K. M. A. Malik, S. A. S. Miller and D. J. Otway, Inorg. Chem. 32, 4464 (1993).
84. S. I. Troyanov, O. Y. Gorbenko and A. A. Bosak, Polyhedron 16, 1595 (1997)

85. V. L. Young, D. F. Cox and M. E. Davis, Chem. Mater. 5, 1701 (1993) and references therein.

86. M. J. Hampden-Smith and T. T. Kodas, Polyhedron 14, 699 (1995).

87. C. Sirio, O. Poncelet, L. G. Hubert-Pfalzgraf and J. C. Daran, Polyhedron 11, 177 (1992).

88. S. N. Wang, J. C. Zheng, J. R. Hall and L. K. Thompson, Polyhedron 13, 1039 (1994).

89. J. A. P. Nash, S. C. Thompson, D. F. Foster, D. J. ColeHamilton and J. C. Barnes, J. Chem. Soc. Dalton Trans. 269 (1995).

90. S. Huang, H. Choi and I. Shim, Chem. Mater. 8, 981 (1996).

91. G. Renner, I. Boie and O. Scheben, Ger. offen 2412784 (1974) Chem. Ab. 84, 43341p (1976).

92. S. Daniele, L. G. Hubert-Pfalzgraf and J. Vaissermann, Polyhedron 14, 327 (1995).

93. D. A. Atwood, A. H. Cowley, R. D. Schluter, M. R. Bond and C. J. Carrano, Inorg. Chem. 34, 2166 (1995).

94. K. F. Tesh and T. P. Hanusa, J. Chem. Soc. Chem. Commun. 879 (1991). 